\title{
LONG RUN EFFECTS OF SOCIAL SECURITY REFORM PROPOSALS ON LIFETIME PROGRESSIVITY
}

\author{
Julia Lynn Coronado \\ Don Fullerton \\ Thomas Glass \\ Working Paper 7568 \\ http://www.nber.org/papers/w7568 \\ NATIONAL BUREAU OF ECONOMIC RESEARCH \\ 1050 Massachusetts Avenue \\ Cambridge, MA 02138 \\ February 2000
}

This paper was presented at the National Bureau of Economic Research (NBER) conference on "The Distributional Effects of Social Security Reform," Woodstock, VT, October 22, 1999. The model used in this paper reflects helpful comments from Henry Aaron, Charles Blahous, Angus Deaton, Martin Feldstein, Steve Goss, Jeff Liebman, Gib Metcalf, Jim Poterba, and Jon Skinner. We are grateful for support from the NBER. This paper is part of the NBER program in Public Economics. Any opinions expressed are those of the authors and not those of the Federal Reserve Board or the National Bureau of Economic Research.

(C) 2000 by Julia Lynn Coronado, Don Fullerton, and Thomas Glass. All rights reserved. Short sections of text, not to exceed two paragraphs, may be quoted without explicit permission provided that full credit, including (C) notice, is given to the source. 
Long Run Effects of Social Security Reform Proposals on

Lifetime Progressivity

Julia Lynn Coronado, Don Fullerton, and Thomas Glass

NBER Working Paper No. 7568

February 2000

JEL No. H22, H55

\begin{abstract}
$\underline{\text { ABSTRACT }}$
This paper uses a lifetime framework to address questions about the progressivity of social security and proposed reforms. We use a large sample of diverse individuals from the PSID to calculate lifetime income, to classify individuals into income quintiles, and then to calculate the present value of taxes minus benefits for each person in each group. In our basic calculations, the current system is slightly progressive, overall, on a lifetime basis. Social Security would become slightly more progressive in one of the reform plans, and it would become slightly regressive in each of the other plans. The pattern of progressivity is affected by alternative assumptions, but it is affected in similar ways for the current system and proposed reforms. None of these reforms greatly alters the current degree of progressivity on a lifetime basis.
\end{abstract}

Julia Lynn Coronado

Federal Reserve Board of Governors

Washington, DC 20551

jcoronado@frb.gov

Thomas Glass

Glass \& Company, CPAs

515 Congress Ave., Suite 1900

Austin, TX 78701

tglass@glasscpa.com
Don Fullerton

Department of Economics

University of Texas at Austin

Austin, TX 78712

and NBER

dfullert@eco.utexas.edu 


\section{Introduction}

Most observers agree that Social Security must be reformed. Although the original "pay as you go" (PAYGO) system was converted to a partially-funded system in 1983, promised future benefits still exceed expected future taxes -- especially by the time the "baby boom" population bulge is done with their retirement. When converted into 1995 dollars, the "intermediate" projected deficit for the year 2075 is $\$ 480$ billion, or just less than 4 percent of projected GDP (Board of Trustees of the Social Security System, 1998).

In addition to serving as a mandatory retirement saving program, Social Security is a program of social insurance with many redistributive elements. Not only does the program redistribute income from current working generations to the retired, but also between families of a given generation in different circumstances. The benefits formula is highly progressive in that it provides a greater replacement rate for workers with lower lifetime earnings. Benefits well in excess of taxes paid are also provided to spouses who do not work, to survivors of deceased workers, and to women in general because they tend to live longer than men. Any reform will alter redistribution under the program, and many proposals give careful consideration to the issue. In general, the current system is considered to be progressive, and most proposals seek to maintain or enhance that degree of progressivity.

In this paper, we estimate the implied changes to the progressivity of the current system from four specific reform proposals. We focus on the retirement portion of the program and the redistribution between rich and poor of a given generation, giving special attention to how we classify economic well-being. We take a steady state approach in that we assume people work and retire under a given system. Thus, we do not address inter-generational redistribution or the issue of transition costs from the present system to any given new system. To define who is rich or poor, we use an estimate of lifetime potential income -- the present value of the total value of 
one's time. We also pool the resources of husbands and wives. A spouse of a high-earner who chooses to stay at home is therefore not misclassified as "poor" under our methodology. We use a large data set of almost two thousand individuals, and classify them into five lifetime income groups. We calculate the present value of the Social Security taxes paid and benefits received for each individual. The difference is divided by lifetime potential income to provide a lifetime "net tax rate." If this net tax rate rises across the five income groups, the system (or reform) is deemed progressive.

We evaluate how four specific reform proposals would alter redistribution from rich to poor. The proposals were chosen to represent the broad spectrum of possible approaches to reforming Social Security. One set of reforms would "privatize" social security, or switch to a system based entirely on mandatory individual accounts with benefits that depend on contributions (e.g. Feldstein and Samwick, 1998). Transition costs aside, such a plan does not redistribute, but provides benefits equal to the present value of one's own contributions. In our model, the net tax rate under such a system is zero and the redistributive consequences of this type of reform are the same as the "repeal" of Social Security. Second, we evaluate the proposal of the National Commission on Retirement Policy (NCRP, 1999). This plan redirects two percentage points of the payroll tax into defined-contribution individual accounts, and it drammatically cuts other benefits to balance the Social Security budget at that reduced tax rate. Third, we look at the plan of Aaron and Reischauer (1998), which suggests smaller specific changes without fundamentally altering the nature of Social Security. In order to close the long-run imbalances, this plan relies heavily on higher returns generated by investing the trust fund in private financial markets. Fourth, we calculate effects of the Moynihan (1999) plan that depletes the current social security trust fund through lower tax rates now and then switches to true "pay as you go" financing.

The model used in this paper was developed elsewhere to evaluate the progressivity of the 
current social security system (Coronado et al, 2000). In that analysis we found that the current system redistributes little, if anything, from rich to poor. In the current paper we find that each of the proposed reforms is a somewhat regressive change to the current system.

The next two subsections describe our model and review the existing literature on the redistributive effects of Social Security. Section 2 provides more detail on the model, and section 3 provides more detail on the four reforms. Section 4 discusses our basic results, and section 5 discusses the sensitivity of those results to alternative assumptions. Section 6 concludes.

\section{I Overview of the Model}

We assume that all working years and retirement years come under a single social security system. Thus we assess long run redistributive effects of the current system and of several reforms. Within this steady state context, we take account of the ways in which social security redistributes across groups defined by income, gender, and marital status. That is, while we report only the redistributions between lifetime income quintiles, we account for heterogeneity within each such quintile. Thus we capture the fact that different income groups have different proportions of individuals who are single or married, male or female, work continuously or sporadically, and who have different mortality rates.

We use twenty-two years of wage rates from the Panel Study of Income Dynamics (PSID) to estimate wage rate profiles for different kinds of individuals (household heads, full-time secondary workers, and part-time secondary workers). The estimated coefficients are used to project each individual's wage rates before and after the sample period, so that each individual has a complete wage profile from age 22 to 66 (extended through 69 for plans with retirement at 70 ). The wage rate for each year is multiplied by a total time endowment to calculate potential earnings, and the present value of this endowment is used to categorize individuals into quintiles 
from rich to poor. Lifetime resources for husbands and wives are pooled so that they are always classified in the same quintile.

Next, for each quintile, actual earnings are used to estimate earnings profiles. We estimate Tobit earnings regressions and again use the coefficients to project out-of-sample earnings for each individual, so that each member of our sample has a complete lifetime earnings history. We then derive income-differentiated mortality rates, and we use those mortality probabilities with constructed earnings histories to calculate each individual's expected lifetime social security taxes and benefits. Finally, we add over the individuals in each quintile to get the net impact of social security on each group under the current system and proposed reforms.

Using actual earnings data is one of the important innovations of our model. As noted below, previous studies use stylized groups, or smoothly-estimated profiles for each group. In contrast, the use of actual earnings data allows us to incorporate differential effects of human capital investment, illnesses, child rearing, and other events that affect earnings and that may lead individuals to enter and exit the labor force. We also give special attention to differential mortality rates by gender, race, and lifetime income.

Distributional effects of the current system also represent the effects of a major reform, namely, repeal of social security or complete privatization. In addition, we calculate effects of three specific reforms, and we compare the progressivity of those reforms to a proportional cut in all benefits (with a comparable overall net tax rate). For each plan, we plot the net tax rate as a function of income. We compare the slopes of these curves because of our interest in long run redistributions between rich and poor, but we ignore the levels of these curves because our model does not capture redistributions between current generations and long-run future generations.

\subsection{Overview of Existing Literature}


The social security system takes taxes from both a high-wage person and a low-wage person during working years, and it provides benefits to both individuals when retired. We wish to measure how much of this money is transferred between individuals, rather than just transferred from the working years to the retirement years of the same person.

Initial tax incidence studies like Pechman and Okner (1974) used groupings based on annual income. This type of study would find that the social security system is progressive, but it aggregates unlike individuals. The low-annual-income group may include both the working poor and those who have retired from a high-earning career. Some later studies like Auerbach and Kotlikoff (1987) include lifetime profiles and lifetime decision making, in order to find how social security redistributes between young and old. However, this study does not distinguish between different lifetime income groups of the same cohort. ${ }^{1}$

Although much work has focused on intergenerational effects of the social security system, Aaron (1977) initiates a growing literature on intragenerational redistribution. Some researchers use arbitrary levels of income for different groups. For example, Hurd and Shoven (1985) and Boskin et al (1987) each use three groups (e.g. median income, half the median, and five-times the median). ${ }^{2}$ The approach of using arbitrarily-set income levels has tremendous computational appeal However, the calculation of social security benefits depends not just on the level of lifetime earnings. Recent years often get more weight, and some years with zero earnings can be dropped from the calculation. Thus the benefits received by each group depend on the

${ }^{1}$ Nelissen (1998) finds substantial differences between annual incidence and lifetime incidence for social security in the Netherlands.

${ }^{2}$ Panis and Lillard (1996) set the low group at full-time minimum wage earnings, the middle group at the Social Security's Average Earnings, and the high group at the social security tax wage cap. Sirvilar procedures are followed by Myers and Schobel (1983), Steuerle and Bakija (1994), and Garrett (1995). 
shape of the earnings profile and the variance from one year to the next. For these reasons, we estimate a nonlinear profile separately for each group. We retain actual earnings data from the sample period and use actual and constructed years of data with zero earnings. Each group has different proportions of individuals with different numbers of zero-earnings years that can be dropped from the benefit calculations (as in Williams, 1998).

Some studies have used actual social security records to look at issues of redistribution [Burkhauser and Warlick (1981), Hurd and Shoven (1985), and Liebman (2000)]. Duggan, et al (1993) use records for more than 32,000 workers from the Continuous Work History Sample of social security records. While using social security records would better identify social security earnings histories, two important elements are missing from the available extracts. First, the observed amount of earnings is generally capped at the annual social security wage cap. Yet only data with wage rates above the cap can fully capture the regressivity of social security taxes that exempt higher wages. ${ }^{3}$ Second, and equally important, records for individuals are not linked with records of spouses.

Fullerton and Rogers (1993) also estimate profiles separately for 12 different lifetime income groups and use them to calculate the incidence of various taxes, but they do not look at social security benefits. More recently, Altig et al (1997) employ the same 12 lifetime income groups in their model of tax incidence, and Kotlikoff et al (1998) use that model to look at social security. These computational general equilibrium models can calculate the effects of social security reforms on factor returns in each period, but each of the 12 groups is assumed to contain homogeneous individuals. Since everyone in a group must work the average amount for that group, these general equilibrium models cannot incorporate heterogeneity such as the fraction in

${ }^{3}$ The true earnings can be estimated, however. För example, Fox (1982) uses information on the time of year that an individual reaches the wage cap to infer the full annual earnings. 
each group who have zero earnings.

For these reasons, we do not attempt to build a general equilibrium model. The point of this paper is to make use of actual data on diverse individuals within each lifetime income group. We can thus use the fact that each group has a different proportion of individuals with zero-earnings years, a different proportion of individuals who qualify for spousal benefits, and a different proportion who receive fewer benefits because they die earlier. In this way, we can look at distributional impacts of specific elements of the social security system. ${ }^{4}$

The literature on distributional impacts of specific elements of the social security system is small. Flowers and Horwitz (1993) look at the spousal benefit, whereby low-earner spouses can draw the greater of their own computed benefit or one-half of the higher-earning spouse's benefit. They demonstrate that the spousal benefit calculation is progressive when compared to an own-benefit calculation. This result is driven by their finding that higher-income families consist of spouses with more-equal earnings and lower-income couples have more disparate earnings. Our data imply the opposite: more-equal earnings among couples with low wages. Also, Panis and Lillard (1996) use a low-medium-high income structure to examine three basic reforms: increasing retirement age, increasing payroll taxes, and decreasing benefits. The effects of these reforms on progressivity are not clear.

Starting with Aaron (1977), some have introduced differential mortality into the analysis. Rofman (1993) uses a data set that matches demographic information from the Current Population Survey with social security information on earnings, benefits, and mortality. However, Duleep (1986) reports that mortality information is severely under-reported in the social security

${ }^{4}$ By concentrating on dollar flows, however, we miss the effect of this social insurance program on the utility of risk-averse individuals (see Geanakopolos, Mitchell, and Zeldes, 1998). The benefits of risk reduction may be larger for low- or high-income individuals. Lee, McClellan and Skinner (1999) calculate such effects for Medicare. 
records, especially for working-age individuals and minorities. Garrett (1995) uses mortality estimates from a literature search, while Panis and Lillard (1996) extract mortality information from the PSID. Since high-income people live longer, several studies show that accounting for income-differentiated mortality seriously dampens the progressivity of social security (e.g.

Steuerle and Bakija, 1994, Duggan et al, 1995, and Panis and Lillard, 1996).

Finally, Caldwell et al (1999) use a large micro-simulation model to construct lifetime earnings for many heterogeneous individuals. This model starts with the 1960 Census Public-Use Microdata Sample and uses estimated transition probabilities to "grow" the sample in one year intervals. For each person, they simulate the next year's income and work status. Thus, as in our study, they capture differences in race, gender, the number of zero-earnings years, differential mortality, and wage rates above the cap. They focus primarily on intergenerational redistributions, finding that while early generations received a good rate of return, post-war generations receive smaller and even negative rates of return.

\section{Lifetime Earnings Profiles and Net Benefits from Social Security}

In this section we describe the data and methodology used to obtain lifetime earnings profiles, to estimate mortality probabilities that differ by lifetime income, and to calculate net taxes from social security. A more detailed description is provided in the Appendix. We use the PSID for the years 1968 to 1989 , which gives us twenty-two years of actual earnings data for a sample of the population. ${ }^{5}$ We select a sample consisting of 1086 heads and 700 wives that is 66 percent of the representative cross-section. The use of a reduced sample suggests the possibility of bias in our econometric estimates and our conclusions about the progressivity of social security. We do

\footnotetext{
${ }^{5}$ While data are currently available through 1992, our model was constructed several years ago when data were available only through 1989 .
} 
not believe our results are biased, for reasons discussed in Appendix A1.

The PSID provides only twenty-two years of actual data. In order to obtain complete profiles of earnings from age 22 through age 66 for each of our sample members, we want to be able to generate out-of-sample earning observations. ${ }^{6}$ We do this by estimating earnings regressions and using the estimated coefficients to generate the needed observations. However, as Fullerton and Rogers (1993) demonstrated using data from the PSID, earnings profiles can have significantly different shapes for different lifetime income groups. We therefore estimate separate earnings regressions for different lifetime income classes.

Our model is somewhat stylized in that we ignore inheritances and transfers. Our measure of annual income is based on wages, which are zero for a retired person. Lifetime income is the present value of that annual income. Note that capital income from lifecycle savings is not part of lifetime income. If the present value of consumption must equal the present value of labor income, then capital income just reflects rearrangements in the timing of consumption.

\subsection{Lifetime Income}

We want to estimate a separate earnings regression for each lifetime income class, and we want a measure of lifetime income that accurately reflects economic well-being. To begin, we calculate an annual wage rate for each member of our sample by dividing annual earnings by hours worked. To construct a wage rate for every year of each sample member's working life, we first

${ }^{6}$ We assume that people work until the future normal retirement age of 67 , claim social security benefits at that point, and do not work after retirement. While the majority of people retiring in the past decade have claimed early retirement, they get a reduction in benefits that is supposed to be actuarily fair. However, early retirees have less education and are more likely to be retiring from blue-collar jobs, indicating that they have lower lifetime incomes (Congressional Budget Office, 1999). 
use all positive wage observations to estimate log wage profiles. ${ }^{7}$ We estimate separate log wage regressions for heads, full-time working wives, and part-time working wives. The results of these regressions can be found in Appendix A2. We regress the log of the wage rate on an individual fixed effect and other variables like age, age-squared, and age-cubed. Because we have a fixed effect for each individual, we cannot use variables that do not vary over time (like race or gender). However, we do include age interacted with education, race, and gender. Using the resulting fixed effects and coefficients, we then fill in missing observations during the sample period and observations outside the sample period. The appendix details how we assign a wage rate to women who have no earnings histories. Non-working wives do engage in household production, and assigning them a zero wage may incorrectly place them in a low lifetime income group for the distributional analysis. Thus, for each individual, we have a wage rate for every year of their entire economic life from age 22 to 66 .

We then use this wage rate and multiply it in each year by 4000 hours to represent the year's labor endowment. This product represents the potential earnings of the individual and therefore serves as a measure of his or her material well-being. ${ }^{8}$ Using this endowment allows us to abstract from the actual labor/leisure choice, since someone who chooses to work less and consume more leisure might be just as well off as someone who decides to work more and consume less leisure. Using potential income also avoids the distortion introduced by the fact that home production does not show up in the data under hours worked. The wage rate is a measure

7 This estimation of a whole life's wage profile takes advantage of the fact that some individuals are in the sample during the early part of their working lives while others are in the sample for the latter part.

${ }^{s}$ For sensitivity analysis, we show net tax rates with two other measures of income: the present value of actual earnings, and the present value of potential earnings where leisure is valued at the average wage rate for the sample instead of the individual's wage rate. 
of earning power that reflects experience, talent, and education. ${ }^{9}$

Once we have a complete wage profile for each of our heads and wives for ages 22-66, we calculate individual gross lifetime income as:

$$
L I=\sum_{i=1}^{45}\left[\left(w_{t} \times 4000\right) /(1+r)^{t-1}\right]
$$

where $t$ indexes the forty-five years in the individual's economic lifetime relevant for social security, ages 22 to 66 , and where the individual could work a maximum of 80 hours per week for 50 weeks per year. Through most of our analysis, we use a value of $2 \%$ for $r$, the real discount rate. Later, we see the effect of changing the discount rate.

As couples generally pool their resources, it would be inappropriate to place husbands and wives individually into separate lifetime income groups. The low-wage wife of a high-wage husband is not "poor". We therefore combine the lifetime income of the husband and wife, and divide by two, to obtain individual lifetime income for each of them. We can now deal with each member of our sample as an individual and categorize them into five lifetime income groups. The first quintile has the lowest income, and quintile five has the highest income.

\subsection{Earnings Profiles}

Once we have people classified into lifetime income groups based on what we feel to be an appropriate measure of economic well-being, we estimate regressions for actual earnings. For each quintile, using our data from the PSID, Appendix A3 describes how we estimate separate earnings regressions for heads, habitually working wives, and occasional working wives, for a

${ }^{9}$ On the other hand, our model may overstate the value of time at home to the extent that it represents sick days or unemployment. 
total of fifteen regressions. We use both positive and zero earnings observations in a Tobit framework.

Because the Tobit framework is nonlinear, we do not include fixed effects as their inclusion would imply inconsistent parameter estimates. The exclusion of fixed effects also means we can use variables in these earnings regressions that do not vary over time, such as education, race, and gender. For each regression for the heads, we begin with independent variables for age, age-squared, age-cubed, education, education-squared, the product of age and education, a dummy for whether the head is female, age interacted with the female dummy, and a dummy for whether the head is white. We then eliminate the variables that were insignificant. We follow a similar procedure for habitually working wives and occasional working wives.

We next use the estimated coefficients from our earnings regressions to simulate earnings observations for the out-of-sample years for all individuals in our sample. ${ }^{10}$ We do not use these coefficients to fill in zero earnings observations during the sample period, as we are interested in actual earnings, and years spent out of the labor force are relevant for calculating the costs and benefits of social security. In fact, we also simulate a representative number of zero earnings years for the out-of-sample portions of each earnings profile.

\subsection{Income-differentiated Mortality}

It is a stylized fact that people with higher lifetime incomes tend to live longer, a fact that can dampen the progressivity of the benefit structure of the social security system. We derive a set of mortality probabilities that vary by race, gender, and our measure of potential lifetime income, so that we can examine the impact of differential mortality on redistribution. Standard

${ }^{10}$ These imputations are independent of each other and are not serially correlated. 
mortality tables extend only to age 85 and are differentiated only by sex and race. As described in Appendix A4, we extend these data in three ways. First, we extend the tables to age 99. Second, since individuals with low incomes have higher mortality rates than the population as a whole, we modify the standard tables by using available information on mortality differentiated by annual income. Third, we then use that information to construct mortality tables that are differentiated among our lifetime income quintiles. In later sections we use these tables to compute expected present values of social security taxes and benefits.

Standard mortality tables are provided in Vital Statistics of the United States (U.S. Department of Health and Human Services, 1993). ${ }^{11}$ For 100,000 individuals alive at age 0 , the table shows the number surviving at each age 1 through 85 . Based on standard mortality tables, a hypothetical 22 year-old white male has probabilities of survival to age 23 of $99.83 \%$, survival to age 65 of $75.82 \%$, and survival to age 85 of $22.34 \%$. We multiply the tax that would be due or the benefit that would be received at each age by the probability of attaining that age, and then calculate the present value of these expected cash flows.

The National Center for Health Statistics obtains death certificates from all U.S. states and constructs four "current life tables" (for white males, white females, nonwhite males, and nonwhite females). Since $31 \%$ of the population is still alive at age 85 , Appendix A4 describes how we extend the tables through age 99 . These expanded mortality tables allow us to weight tax payments and benefits by the probability of being alive in each year from age 22 to 99 .

Many studies have noted that mortality rates for the poor are higher than average. $A$

11 An alternative source of data for our analysis of a hypothetical future cohort would be projected mortality tables from the Social Security Administration which incorporate projected increases in life expectancies. Using SSA's probabilities would decrease the net tax rate for everyone, as people live longer and draw benefits longer, but it would have no effect on our adjustments for mortality probabilities that differ by lifetime potential income and so would not substantively alter our conclusions on redistribution. 
Mortality Study of 1.3 Million Person (Rogot, et al, 1992) provides a rich source of data on this effect. They show the observed number of deaths for each annual income class of each race, gender, and ten-year age group. For each such cell, we divide observed deaths, $O$, by the expected deaths, E, that would occur if all income classes of that group had the same mortality rate. We then apply that $\mathrm{O} / \mathrm{E}$ ratio to each cell in the extended mortality tables. Among white males aged 25-34, for example, those in the poorest annual income group die at a rate that is $168 \%$ of the average, while those in the richest annual income group die at rate that is only $61 \%$ of the average. For nonwhite females of the same age, the poor die at a rate that is $186 \%$ of the average, while the rich die at a rate equal to $44 \%$ of the average.

Although we have the annual household income of each individual in our sample for each year, we do not just use the corresponding annual income group's O/E ratio for that person in that year to weight their mortality probability. Using annual income would imply that an individual with a steeply hump-shaped earnings profile would have a probability of dying that falls dramatically during high-annual-income years and then rises again during low-annual-income years. We do not believe that the same individual's probability of death changes that rapidly with annual income, jumping over other individuals in the same age cohort whose annual incomes are not so volatile. Instead, the probability of dying is more likely affected by the individual's lifetime income. To address this issue, our procedure described in Appendix A4 is based on the relative ranking of each individual's lifetime income. Basically, a person in a particular percentile of the lifetime income distribution is assigned the $\mathrm{O} / \mathrm{E}$ ratio of a person in the same percentile of the annual income distribution. ${ }^{12}$

${ }^{12}$ Thus, even if two retirees have the same low annual income, the one with higher lifetime income is assumed to have a lower mortality probability. 


\subsection{Social Security Taxes Paid}

We next compute the value of social security taxes for each person in each year, following the provisions of the Social Security Administration. This tax is commonly called the FICA tax (Federal Insurance Contributions Act). It is collected on earned income and consists of three portions: Old Age and Survivors Insurance (OASI), Disability Insurance (DI), and Hospitalization Insurance (HI), also known as Medicare. The proceeds from these taxes are deposited into three separate trust funds, and benefits are paid from the appropriate fund. The program has become almost universal -- 95\% of all employment in the U.S. is covered. ${ }^{13}$

The tax is deducted from employees' pay at a rate of $7.65 \%$ of wages, but employers match those deductions for a total tax of $15.3 \%$. Self-employed individuals pay the entire $15.3 \%$ tax annually with their income tax returns. Both the employee and employer shares of the tax are collected on wages up to an annual maximum amount of taxable earnings -- the social security wage cap $(\$ 76,200$ for 2000$)$. This cap is adjusted automatically each year with the average earnings level of individuals covered by the system, thereby accounting for both real wage growth and inflation.

Since an objective of our research is to measure each worker's net social security tax burden, the question arises: how much of the total FICA tax does the worker bear? Using only the statutory incidence (the worker's half) would yield much lower burdens than using the combined employer and employee portions. Hamermesh and Rees (1993, p.212) review empirical work on payroll tax incidence and conclude that the worker bears most of the employer's share of

${ }^{13}$ Coverage may be excluded for: federal civilian workers hired before 1984 who have not elected to be covered; railroad workers who are covered under a similar but separate program; certain employees of state and local government, covered by their state's retirement programs; household workers and farm workers with certain low annual incomes; persons with income from self employment of less than $\$ 400$ annually; and those who work in the underground, cash, or barter economy who may illegally escape the tax. 
the tax through reduced wages. We therefore base our estimates on the combined employer and employee $\operatorname{tax}^{14}$

Our focus is the retirement portion of the social security system, not the disability insurance or hospital insurance portions. Of the total $15.3 \%$ tax rate, $2.9 \%$ is for Medicare (HI), leaving $12.4 \%$ for OASDI. This is the rate cited and modified by certain reform proposals, even though $1.8 \%$ goes to Disability Insurance (DI). The remaining $10.6 \%$ is for Old Age and Survivors Insurance (OASI), and this is the tax in our model. ${ }^{15}$ The OASI portion of the tax is paid directly to the OASI Trust Fund, which is used to pay all retirement benefits. We ignore the DI and HI portions of the tax, as well as benefits paid from the DI and HI Trust Funds. In essence we assume that no one becomes disabled prior to retirement. If a sample member has few earnings observations because they became disabled, they are treated as any other person with many years out of the labor force.

Our sample from the PSID includes observed and constructed earnings for each individual from age 22 until retirement. To obtain steady-state taxes and benefits under current law, however, we look at a hypothetical future cohort with a birth year of 1990 . We therefore take $\mathrm{N}_{\text {oij }}$, the "observed" nominal earnings of individual $\mathrm{i}$ in year $\mathrm{j}$, and we convert it to the corresponding future individual's nominal earnings, $\mathbf{N}_{\mathrm{tij}}$, using the ratio of projected average

${ }^{14}$ Panis and Lillard (1996) point out that because the employer's portion of the payroll tax is deductible against the employer's income tax, the net cost to the employer is lower than the full amount of the payroll tax paid. Like Panis and Lillard, however, and for comparability with other studies, we treat the entire payroll tax as the employee's cost of social security coverage. In effect, we look at the social security system only, without any income tax. The combined incidence is not equal to the sum of the parts, but we cannot say whether the income tax affects the incidence of social security, or social security affects the incidence of the income tax.

${ }^{15}$ These allocation percentages are for the year 2000 and beyond. Congress "temporarily" increased the portion going to DI for the years 1994 to 1996 , followed by a reduction for 1997 1999. The 1997 allocation is: OASI $=10.7 \%, \mathrm{DI} \%=1.7 \%$, and $\mathrm{HI}=2.9 \%$. 
earnings in the future year $\left(\mathrm{AE}_{\mathrm{ff}}\right)$ to observed average earnings in the PSID sample year $\left(\mathrm{AE}_{\mathrm{oj}}\right)$ :

$$
N_{\mathrm{rij}}=\mathrm{N}_{\mathrm{oij}}\left(\mathrm{AE}_{\mathrm{ij}} / \mathrm{AE}_{\mathrm{oj}}\right)
$$

Since 1951, the Social Security Administration has computed Average Earnings, the average annual earnings of all workers covered under the Act. We project this Average Earnings into the future using assumptions about future real wage growth and inflation. ${ }^{16}$

In our study, we calculate the present value at age 22 of mortality-adjusted social security taxes and benefits through age 99. Again, we assume that each person works and retires under a given system. The probability $P_{i j}$ of individual $i$ being alive at age $j$ is conditional on being alive at age 22, and it is computed from the constructed tables (for each age-race-sex-income cell) as the number in cell $i$ alive at age $j$ divided by the number in cell $i$ alive at age 22 . We then calculate $E\left(\operatorname{SST}_{\mathrm{ij}}\right)$, the expected social security tax of person $i$ in year $j$, as:

$$
\mathrm{E}\left(\mathrm{SST}_{\mathrm{ij}}\right)=\left[\mathrm{T} \times \operatorname{Min}\left(\mathrm{N}_{\mathrm{ij}}, \mathrm{CAP}_{\mathrm{j}}\right)\right] \times \mathrm{P}_{\mathrm{ij}}
$$

where $T$ is the combined OASI tax rate (which is constant with unchanged law), CAP $_{j}$ is the maximum nominal earnings subject to the OASI tax (which increases with inflation), and $P_{i \mathrm{i}}$ is the probability that person $i$ is alive at age $j$. These amounts are used to compute the present value of social security taxes paid.

\subsection{Social Security Benefüs}

${ }^{16}$ We use actual inflation and growth to scale obsèrved PSID years up to 1995. Since amounts in future years are indexed, the subsequent inflation and growth rates are set to zero. 
Under provisions of the Social Security Act, benefits are calculated from a progressive formula based on the individual's Average Indexed Monthly Earnings (AIME). Our calculations follow the Social Security Administration's computation of AIME upon the individual's retirement. In particular, earnings prior to age 60 are indexed to average wages in the year the individual attains age 60 . Only earnings at or below the taxable cap in each year are considered. The method of indexing is to multiply the nominal earnings in year $\mathrm{j}$ by the ratio of Average Earnings in the year age 60 was attained to Average Earnings in year j. Earnings after age 60 are not indexed. A person who works from age 22 through age 66 (retiring on his or her 67 th birthday) would have a total of 45 years of earnings. Under the Act, only the highest 35 years are considered, so the ten lowest years will be dropped. AIME is the simple average of the indexed earnings in those 35 highest-earnings years. ${ }^{17}$

Next, the Primary Insurance Amount (PIA) is calculated as $90 \%$ of AIME up to the first bend point, plus $32 \%$ of AIME in excess of the first bend point but less than the second bend point, plus $15 \%$ of AIME in excess of that second bend point. The fact that only capped earnings are used to calculate AIME provides a de facto maximum benefit. In 1995, the bend points were $\$ 426$ and $\$ 2,567$. If AIME were $\$ 3,200$, for example, the PIA would be:

$$
\mathrm{PIA}=.90 \times(426)+.32 \times(2,567-426)+.15 \times(3,200-2,567)=\$ 1,163.47
$$

Like the cap on earnings, the bend points are adjusted annually by the proportional increase in Average Earnings. We calculate this PIA for each worker in the sample.

${ }^{17}$ The language of the Act specifies dropping the five lowest years of earnings through age 61. Then, if the worker has years of earnings after age 61 that are higher than some earlier years' earnings, the higher post-61 earnings will replace those lower earnings. The net effect for a worker retiring at age 67 is to drop the ten lowest years. 
A retiree is entitled to a benefit equal to the Primary Insurance Amount upon "normal" retirement at age 67 . A worker may still choose to retire as early as age 62 , with reduced benefits. ${ }^{18}$ In contrast, if a worker elects to delay receipt of benefits to an age as late as 70 , the eventual benefits are permanently increased by $5 \%$ per year of delay. Our calculations below ignore these provisions for early or late retirement, as we assume workers (and their spouses) always choose the normal retirement age, ${ }^{19}$ which for our hypothetical cohort under the current system is 67 .

In addition to retirement benefits for covered workers, the OASI Trust Fund provides certain benefits to the spouse and other dependents of retired or deceased workers. The spouse of a retired worker can receive the greater of the benefit based on his or her own earnings, or onehalf of the PIA of the retired worker (designated as the "spousal benefit"). The spouse of a deceased worker can receive the higher of the benefit based on his or her own earnings, or $100 \%$ of the benefit to which that worker was entitled. The benefit based on the deceased worker's benefit is called the "survivor benefit". We ignore non-spousal survivor benefits; in aggregate they are relatively minor. ${ }^{20}$

Our calculations of these amounts are detailed in Appendix A5. We use each individual's observed and constructed earnings to compute Average Indexed Monthly Earnings (AIME), the

${ }^{18}$ This early retirement penalty is a permanent reduction in the PIA of 5/9\% for each early month (6.67\% for each early year). For example, a worker retiring at age 64 when the normal retirement age is 67 would receive a benefit for the rest of his or her life that is reduced by $20 \%$.

${ }^{19}$ This assumption does not affect progressivity unless the chosen date of retirement differs by income. If low-income individuais tend to die earlier, then they might optimally retire earlier, so the availability of this option might be progressive.

${ }^{20}$ In 1996 , a total of $\$ 302.9$ billion in benefits were paid from the OASI trust fund. Of that total, $\$ 288.1$ billion was paid to retired workers or their spouses, and only $\$ 14.8$ billion (4.9\%) was paid for the other survivor and miscellaneous benefits (Annual Statistical Supplement, 1997, Table 4A.5). 
Primary Insurance Amount (PLA), the Spousal Benefit (SpBen), and the Survivor Benefit for the surviving spouse (SurvBen) in exact accordance with provisions of the Act.

\subsection{Present-Value Net Tax Rates}

After we calculate the mortality-adjusted tax and benefit in each year for each individual in each of our lifetime income quintiles, we compute the present value, at age 22 , of the benefits to be received minus the taxes paid. We then add over the individuals in each lifetime income quintile. We divide by the present value at age 22 of the lifetime endowment (discounted at the same rate) to get an effective net tax rate for each group. A system that takes the exact same fraction of income for all groups is "proportional", whereas a system that takes a higher fraction of the income of the rich (poor) is deemed progressive (regressive).

The discount rate should reflect a real rate of return that would be available to participants in the system and that would provide for the same certainty as does the Social Security System. The Trustees of the Social Security System currently used a rate of $2.8 \%$ for their long-term estimate of real returns in their 1998 report. $^{21}$ Ibbotson Associates (1998) reports on historic rates of return for various portfolio investments. For the period 1935 to 1997 , the average inflation rate was $4.0 \%$, and the nominal return on intermediate-term U.S. Treasury obligations was $5.4 \%$, so the real rate of return was $1.4 \%$.

For one choice of discount rate we use $2 \%$, which lies between the forecast rate earned by the OASI trust fund on its investments $(2.8 \%)$ and the historical average of real returns on

${ }^{21}$ In arriving at that rate, they forecast inflation at a long-term rate of $3.5 \%$, and a nominal interest rate of $6.3 \%$ on the special-issue U.S. Treasury obligations that are purchased by the OASI trust fund. Whether to use a before-tax or after-tax discount rate depends on one's assumption about what alternative retirement investments are available. 
government bonds reported by Ibbotson $(1.4 \%){ }^{22}$ To test the sensitivity of results, we also use a discount rate of $4 \%$. As shown below, the choice of rate impacts not only the absolute size of the present value gains or loss for each group but also the pattern of progressivity.

\section{Proposed Reforms and their Treatment in our Model}

Our evaluation of social security reform is limited in many respects. First, since we focus on distributional effects, we ignore behavioral effects such as changes in labor supply or savings. Second, since we cannot evaluate all of the many suggested reform proposals, we focus on only four of the major ones. Third, since most of these proposals are still evolving, we evaluate only versions that were available in written form in early 1999 . Fourth, since each such proposal is too complicated to capture fully in our model, we really just evaluate "stylized" versions of these reforms. In particular, since we consider only long run provisions, we ignore any phase-in of a change in the normal retirement age. ${ }^{23}$ Since we assume everybody retires at that normal retirement age, we also ignore the effects of proposed changes in the early retirement age. And since we have only one "discount rate" in our model, with no consideration of risk, we cannot capture the welfare effects of any plan to switch some of the social security trust fund from government bonds to investments in corporate stocks and bonds.

Because we miss some of these ways in which each reform might raise net revenue,

22 Other studies of social security redistribution have used rates on either side of $2 \%$. Myers and Schobel (1983) use 2\%, Hurd and Shoven (1985) use 3\%, Boskin, et al (1987) use $3 \%$, Duggan, et al (1993) use $1.2 \%$, Steuerle and Bakija (1994) use 2\%, and Gramlich (1996) uses $2.3 \%$. In contrast, Caldwell et al (1999) use $3 \%, 5 \%$, or $7 \%$.

${ }^{23}$ Legislation already enacted will increase the retirement age by two months each year beginning in 2000 , so that by 2005 the normal retirement age will be 66 . Another two month per year increase will begin 2017, resulting in a normal retirement age of 67 after the year 2021 . All of the reform proposals we consider would eliminate the pause (from 2005 to 2017) and reach the new higher normal retirement age sooner. 
especially during the transition, we cannot comment on the extent to which each reform might close the existing social security deficit. Each plan extends the solvency of the program to 75 years. Some extend solvency indefinitely, while others have large annual cash flow deficits at the end of 75 years. Thus each of the plans evaluated are different in present value, and the long-run features that we consider raise different amounts of net revenue for each plan. As a consequence, some of the plans appear in our model to have higher overall net tax rates than others. We emphasize, however, that our goal is to compare the progressivity of these plans and not their overall net tax rates.

As described above, we do capture the major long run provisions of social security that determine taxes and benefits for individuals in different circumstances. We now describe proposed changes to these provisions, as summarized in Table 1. The first column of this table represents the current system. It does not list all features of the current system, only the main ones that would be reformed by one of the plans.

\subsection{The Feldstein-Samwick Plan}

A number of proposals would completely privatize social security. The proposal outlined by Feldstein and Samwick (1996) is typical of these plans. It specifies a transition from the current system to one in which the benefits are equivalent to those guaranteed under the current system, but where these benefits in the long run are funded entirely by mandatory contributions to individual accounts made over a lifetime. The balances in the individual accounts would be invested in private debt and equity markets.

We do not explicitly model the Feldstein-Samwick plan, or any other plan based on individual accounts, as such plans involve little or no redistribution (except to the extent that some 
privatization plans include minimum benefits and survivor benefits). ${ }^{24}$ In our modeling framework, such plans are equivalent to repeal of the system. Our model is better suited to capturing the effects of reforms that do not alter the basic tax and benefit nature of the current system. Thus, in our model, the effects of the Feldstein-Samwick plan are the opposite of the effects of having the current social security system.

\subsection{The National Commission on Retirement Policy (NCRP) Plan}

The NCRP (1999) proposal is also associated with the names of Senators Breaux and Gregg and Representatives Kolbe and Stenholm. One version is a "defined benefit" (DB) plan based on the current OASDI tax rate, but we evaluate only the other version that sets aside 2 percentage points of each person's tax into a mandatory "Individual Savings Account" (ISA). Since each retired individual receives back his or her own ISA, plus earnings, such a mandatory savings plan does not redistribute between members of a generation in the long-run. It has a net present value tax of zero for each individual and therefore does not enter our calculations. The remaining "tax and benefit" portion of this plan is scaled back from current law. As shown in the first row of Table 1, the OASDI tax rate is cut from $12.4 \%$ to $10.4 \% .^{25}$ The next row shows that this plan does not change the wage cap.

With taxes cut substantially, closing the social security deficit means that benefits must be cut dramatically. The NCRP plan cuts benefits in several ways. The largest cut is in the calculation of benefits cailed the "primary insurance amount" (PIA) in equation (4). In that

${ }^{24}$ Also, individual accounts that require annuitization at a single rate will retain some redistribution due to differential mortality, see Brown (2000).

${ }^{25}$ These reforms state changes in terms of the current $12.4 \%$ OASDI rate, as shown in the Table. However, 1.8 percentage points of that tax go to disability insurance (DI), and we model only OASI. With the 2 points diverted into ISA accounts, the $10.6 \%$ OASI rate becomes $8.6 \%$. 
calculation, "PIA factors" are applied to average indexed monthly earnings (AIME) between the bend points. As shown in the third row of Table 1, the long-run NCRP plan would still provide $90 \%$ of AIME up to the first bend point, but the $32 \%$ rate between the two bend points is cut to $21.36 \%$, and the $15 \%$ rate above the second bend point is cut to $10.01 \%$. Thus benefits are cut disproportionately for high-income individuals. This change is progressive, even in a lifetime context, as we confirm below.

In fact, this plan adds benefits to low-income individuals, another progressive change. Current law has a small "minimum benefit" that depends on the number of quarters of earnings but that can reach as high as $\$ 6,235$ per year (at 1995 levels, but indexed). As indicated in the next row of Table 1, the NCRP plan would raise this minimum benefit to the indexed "aged individual poverty level" (AIPL), which was $\$ 7,761$ in 1995 (a $24 \%$ increase).

The next biggest cut in benefits occurs through the NCRP's increase in the ultimate normal retirement age (NRA) from 67 to seventy. ${ }^{26}$ This change is regressive for three reasons. First, it means that individuals will work and pay taxes for more years, and those taxes are generally regressive because they apply only to earnings below the wage cap. Second, it means that individuals will retire later and receive benefits for fewer years. Since the benefit schedule is progressive, that cut in benefits is regressive. Third, because of income-differentiated mortality, the higher retirement age means that low-income individuals have a disproportionate increase in the chance of dying before they receive retirement benefits.

The NCRP plan also changes the number of years' earnings used in the AME calculation.

${ }^{26}$ Like other reforms considered here, the NCRP plan would also later increase the NRA above 70 to account for subsequent increases in longevity (to maintain a constant number of expected years of life after retirement. We cannot model this provision as an increase in the retirement age, unless we were also to raise survival probabilities (which would roughly maintain the expected number of years of benefits). 
Current rules use 35 years, which means that ten years of low earnings can be dropped from the calculation. This includes the five years that can be dropped before the AIME calculation at age 62 , and the additional five years of earnings after age 62 that can be used to replace lower earnings from before 62. The NCRP plan says it would "include earnings for all years", and we interpret this to mean all years up to the AIME calculation. Since the NCRP plan raises the early retirement age (and AIME calculation) from 62 to 65 , the individual can still use five subsequent years of earnings (until retirement at age 70) to replace lower earnings from before 65 . In other words, effectively, 5 years still can be dropped. ${ }^{27}$

Under current law, any married retiree can receive the higher of one's own benefit or half of what the spouse receives. This latter option is called the "spousal benefit." The next row of Table 1 shows that the NCRP plan would allow only one-third of the spouse's benefits. This cut would most affect any person whose income is low relative to his or her spouse, but remember that we do not count that person as "poor" (because we assume each person gets half of the couple's total income). Perhaps surprisingly, this change is slightly progressive. As it turns out, middle and high income couples have more disparate incomes and make greater use of the spousal benefit.

While the current system is fully indexed for inflation, it uses the consumer price index (CPI). This index has been criticized for overstating inflation and therefore scaling up benefits by more than necessary to maintain living standards for retired beneficiaries. The NCRP plan, like other reform plans, would require a downward revision in the CPI, which would raise some net

${ }^{27}$ In Coronado, Fullerton, and Glass (1999), we use the same model to analyze the redistributive impact of specific reform components. We found any reduction in the number of drop years allowed to be a regressive reform. Including the low earning years reduces AIME somewhat more for low income workers because they have more zero earning years. In addition, that decline in AIME reduces benefits at the 90\% PIA-factor for individuals below the first bend point, and it reduces benefits at a low PIA-factor for those with income above the bend points. 
revenue. If the issue was just described in terms of accurate indexation for inflation, then we would not be able to capture this provision. If the Bureau of Labor Statistics does not change the CPI, however, the reform says that benefits will be indexed explicitly to the CPI minus 0.5 percentage points. We model that change as a real cut in benefits. Specifically, real benefits fall at $0.5 \%$ per year, starting at the age of retirement. Since the benefit schedule is progressive, any cut in benefits would normally be regressive. However, benefits are cut more for those who live longer and continue to experience real benefit cuts each year. Since high-income individuals live longer, this particular form of benefit cut has uncertain effects. As it turns out, the net effect of this provision is somewhat regressive in our model.

Thus, some aspects of the NCRP plan are progressive, and some are regressive. Our calculations below will show the net effects of all these changes together. Table 1 also lists a few provisions that are not captured by our model. The NCRP plan would also raise the age for early retirement from 62 to 65 (to match the three-year increase in the normal retirement age from 67 to 70). It would extend OASDI coverage to all State and local government employees hired after 1999. Under current law, if a social security beneficiary works after normal retirement age, retirement benefits are reduced by $\$ 1$ for every $\$ 3$ that are earned above some threshold. This feature is not captured in our model, because we assume no earnings after retirement. The NCRP plan would also eliminate this retirement earnings test for individuals after normal retirement age (70).

\subsection{The Aaron and Reischauer (A\&R) Plan}

Any reform plan must face fundamental choices about the very nature of social security. The current system is "partially funded," so a reform could raise revenue and create a fully funded program, or it could return to the original "pay as you go" (PAYGO) idea. The current system is 
explicitly a transfer program that redistributes from workers to retirees, to those with low income, to non-earning spouses, and to women (because they live longer). Any reform could choose to remove those transfer elements, or it could choose to enhance them.

Rather than make wholesale changes to social security, the plan of Aaron and Reischauer (1998) would "fix" the current system. It would "close the projected long-term deficit and make Social Security better reflect current social and economic conditions, while preserving Social Security's fundamental character" (p. 96). As a consequence, this plan tinkers with a number of provisions in ways that each raise a bit of revenue while closing a significant portion of the projected shortfall by investing the trust fund in private debt and equity markets.

The A\&R plan is summarized in the third column of Table 1. As it turns out, many of these changes appear at the bottom of the column, under features "not captured by our model." The A\&R plan would raise the earliest eligibility age (EEA) to from 62 to 64 (to match the currently provided two-year increase in the normal retirement age from 65 to 67). Like other plans, it would cover all new State and local employees. Whereas current law collects income tax on social security benefits only above some threshold, the A\&R plan would tax social security benefits just like it were a private pension. ${ }^{28}$ As mentioned above, the A\&R plan would also raise some money by switching part of the Social Security trust fund from government bonds to higheryielding corporate stocks and bonds. We use only one discount rate, ignoring different risk premia, so we do not capture this provision either. We might note, however, that many of these ignored provisions have no obvious implications for redistribution.

The top of the third column shows the provisions of the A\&R plan that are captured in

28 That means it would exempt the amount that was already subjected to income tax (such as the employee's payroll tax share, which comes out of taxable income), but it would tax the rest of social security benefits -- since those dollars have not yet been subject to income tax. 
our model. First, this plan would change the number of years of earnings used in the AIME calculation from 35 to 38 . Including more low-earning years means that AIME is reduced, and thus benefits are lower. The calculation still drops four years before the AIME calculation, and it still uses three more years (from 64 to 67) to substitute for earlier low-earning years. Thus it drops the 7 lowest earning years to age 67. Like the NCRP plan, the A\&R plan would raise a little money by cutting the spousal benefit from one-half to one-third of the benefits of the higherearning spouse. As mentioned above, the reduction in the number of dropped years is regressive and the reduction in the spousal benefit is somewhat progressive -- at least by our measurements where each spouse's well-being is based on half of the couple's lifetime income.

Next, the A\&R plan makes a change to the "survivor's benefit," which currently allows a widow or widower to receive his or her own benefit or the deceased spouse's benefit (whichever is larger). In the table, this rule is represented by "Max(Hus, Wife)". Instead, the A\&R plan would provide three-quarters of the combined benefits of both spouses ["3/4(Hus+Wife)"]. The logic for this change is based on the cost-of-living for one person compared to the cost for two together. Compared to current law, however, it provides more benefits to some individuals and less to others. If two spouses had the same earnings, for example, then either person's survival benefit would become three-quarters of the total, which is $50 \%$ more than under current law (where either person would get half of the total). If a lower-earning spouse had own benefits of less than $1 / 3$ of the higher-earning spouse, then either person's new survivor's benefit would be less than under current law. ${ }^{29}$ In our calculations, this particular provision is found to be progressive. As mentioned above, low-income couples tend to have more similar incomes, since both must work at low-paying jobs. Equal incomes gain from this reform provision. Middle and

${ }^{29}$ The breakeven point is where one's benefit is a third of the higher earning spouse's benefit, because $3 / 4$ of (one plus one-third) equals max(one-third, one). 
high-income couples tend to have more disparate incomes, since they can afford for one person to stay at home, and thus gain less or actually lose from this proposal.

Finally, the A\&R plan would undertake unspecified corrections in the consumer price index (CPI). The reasoning is the same as that described above, namely, that the current CPI has been criticized for growing too fast. This plan would leave those corrections to the economics experts, however, and not subtract any number of points from the CPI. With the system fully indexed to an accurate measure of inflation, we assume that real benefits are maintained.

Again, some of these provisions are progressive and some are regressive. Most are small, however, and so the overall progressivity of the A\&R plan is not expected to differ much from that of current law. As shown below, the A\&R plan is slightly more progressive than the current Social Security system.

\subsection{The Moynihan Plan}

In terms of fundamental choices about the nature of Social Security, Senator Moynihan's (1999) reform proposal would head in a different direction. Whereas the 1983 changes raised revenue to generate a partially-funded Social Security trust fund, this plan would return to "pay as you go" (PAYGO). The current trust fund would be drawn down by a temporary reduction in the current $12.4 \%$ OASDI tax rate to $11.4 \%$ (for 1999-2000) and to $10.4 \%$ (for 2001-2024). Then, when the trust fund is depleted, and that tax on a smaller number of workers is not enough to cover the benefits for a larger number of retirees, the rate would have to rise again to $11.4 \%$ (for $2025-29$ ), $12.4 \%$ (for $2030-44$ ), $12.7 \%$ (for $2045-54$ ), $13.0 \%$ (2055-59), and $13.4 \%$ thereafter. These numbers are summarized in the top of the fourth column of Table 1.

Since our model considers only the long-run provisions of these reforms, the Moynihan Plan has to be represented by the $13.4 \%$ tax rate. We show results with the $13.4 \%$ rate in our 
tables below. In the long run, with this rate, overall net tax rates on all individuals are substantially higher than for the other reforms (and higher than for current law). The reason is that this plan disperses the trust fund to those of us in current generations -- by lowering our overall net tax rates. For this reason, results below also show the effects of the Moynihan Plan with the low $10.4 \%$ rate.

The wage cap is $\$ 76,200$ in 2000 , and it is projected to reach $\$ 82,800$ in 2003 . As indicated in the second row of the table under the current system, this wage cap will cover about $85 \%$ of wages. This percentage has been falling, because high wage rates have been growing faster than average wages. The Moynihan Plan would raise the wage cap to $\$ 97,500$ in 2003 , which would cover about $87 \%$ of wages, and it would still be indexed thereafter. We calculate the real increase in the long-run wage cap for our model. This change is progressive, because it collects additional payroll tax from those above the current wage cap. On the other hand, we should note, the increase in the OASDI tax rate to $13.4 \%$ is regressive, given any wage cap, because it collects only from those below the cap. Again, our model can calculate the net effect on progressivity.

The Moynihan plan also speeds up the currently-scheduled increase in the normal retirement age to 67 , and it continues that increase to the age of 70 (for those retiring in 2073 and later). This change is regressive, for three reasons mentioned above: first, individuals pay the regressive payroll tax for more years, and second, they receive the progressive benefit schedule for fewer years. Third, low-income workers also die sooner, so the fall in their survival probability from age 67 to 70 is greater than for high-income workers.

Since it increases the normal retirement age by three years (from 67 to 70 ), the Moynihan Plan also increases the number of years of earnings in the AIME calculation by three (from 35 to 38). The lowest ten years of earnings are still ignored. This change is regressive, for reasons 
mentioned in footnote 27.

Like the NCRP, the Moynihan plan requires a reduction in the index used to maintain real benefits after retirement. If those corrections are not made within the CPI, then benefits will be indexed by the CPI minus one percentage point. We model this change as a one percent cut in real benefits each year after retirement.

The bottom of the last column of the table indicates the provisions of the Moynihan Plan that are not captured by our model. Like other reforms, it extends coverage to all new State and local workers. Like the NCRP plan, it eliminates the current earnings test for those beyond the retirement age who work. While the NCRP plan would eliminate this test at age 70 , the Moynihan plan would eliminate it at age 62. Finally, like the Aaron\&Reischauer Plan, the Moynihan plan would change the income tax to cover all Social Security benefits as if they were private pensions.

\section{Results}

Our initial simulations use the enacted provisions of the Social Security Act, applied to a future cohort born in 1990. Results are presented in Table 2. The first row shows the overall average undiscounted taxes paid minus benefits received, in thousands of dollars per person. The reason for showing undiscounted net taxes is to shed some light on the overall solvency of the social security system. Our model cannot project actual inflows and outflows, since we do not use demographic forecasts, but a conceptual point can be made about solvency in a world with unchanging demographics: with a constant number of entering 22-year-olds in each of the sex-race-income cells in our model, the undiscounted sum of taxes paid per individual $(\$ 103,200)$ equals the sum of taxes paid by all ages alive at one time. Similarly the undiscounted sum of benefits ( $\$ 164,900)$ is the sum of benefits paid out to all ages alive at one time. On this basis, the 
current social security system loses the difference $\left(\$ 61,700\right.$ per 22 -year-old) each year. ${ }^{30}$

The first column of Table 2 shows the net tax as a fraction of lifetime potential income for each quintile under the current system. This net tax rate rises from $0.62 \%$ for the lowest-income quintile to $1.01 \%$ for the highest-income quintile. Thus current law is progressive, but not uniformly so. The highest net tax rate applies to the middle-income quintile $(1.07 \%)$. The benefit structure is progressive, even on a lifetime basis, but that progressivity is largely offset by the regressive tax system (which exempts earnings above the wage cap) and by various features of the system that tend to favor high-income groups (like the fact that high-income individuals tend to live longer and therefore receive benefits longer).

A large number of recent articles on social security reform have dealt with privatization of the system or other large-scale overhauls of the program (e.g. Kotlikoff et al, 1998). If complete privatization were to provide actuarially-fair returns, with no redistributions between individuals, then the effects of complete privatization in our model are exactly the reverse of having the current social security system. Thus, the results in this first column for the current system can be viewed as the distributional impact of an extreme reform -- repeal of social security. Because the current system is progressive, its repeal would be a regressive change.

Feldstein and Samwick (F\&S, 1996) do not suggest repeal of the current system, but instead outline a plan to make it solvent and actuarially fair. Most importantly, their plan deals with the costs of a transition that honors the currently-promised benefits to existing generations. That transition does not show up in our long-run model. If the F\&S plan is actuarially fair, in the

${ }^{30}$ If we multiply this $\$ 61,700$ figure by the number of 22 -year-olds alive in 1994 (about 3.7 million), we get a total loss of about $\$ 228$ billion per year. This figure lies between the "low" and the "high" deficit projected by the Board of Trustees of the Social Security System (1998). As mentioned above, their "intermediate" projected deficit for 2075 is $\$ 480$ billion in 1995 dollars, but that includes DI and pertains to a larger population. 
long run, then it does not take net taxes from anybody. The second column of Table 2 shows these zero net tax rates in the top panel, and the change from current law in the bottom panel. To the extent that our calculations accurately reflect the long-run progressivity of the current system, the change to zero tax rates would be a regressive change, but not uniformly regressive.

The results in Table 2 are illustrated in Figure 1, where the net tax rate for the current system is the lowest of these six lines, rising from $0.62 \%$ for the first income group to $1.07 \%$ for the middle group and $1.01 \%$ for the high income group. The Feldstein-Samwick plan would be represented by the horizontal axis, with zero tax rates for all groups.

The NCRP plan has both progressive and regressive elements. It would lower the regressive payroll tax by 2 percentage points and make the benefit schedule more progressive, but it would also cut benefits by raising the retirement age, by including more years of earnings in the benefit calculation, and by reducing the CPI by 0.5 percentage points. Since benefits generally are progressive, these benefit cuts are regressive. The net effects of all these changes are shown for the NCRP plan in the third column of Table 2. The net tax rate on the lowest income group would rise to $1.83 \%$, but the rate on the highest income group would rise to only $1.77 \%$. Again the middle group pays the highest tax rate $(2.15 \%)$. The bottom panel of Table 2 shows that the increase in tax rate is highest for the group whose income is lowest. Thus the reform is a regressive change to the current system. On the other hand, Figure 2 shows that the NCRP system overall is pretty flat, with a net tax rate around $2 \%$ of lifetime income for all groups.

The top of the NCRP column in Table 2 shows the annual shortfall. By raising the net tax rate for everybody, the NCRP plan is able to reduce the annual shortfall as measured in our model from $\$ 61,700$ per person to only $\$ 5,600$ per person (and provisions that we do not capture may raise the rest of the needed revenue to balance the social security budget). Yet, one might ask, if "balance" means that all social security benefit payments are covered by payroll taxes, then why is 
the net tax rate still positive (at about $2 \%$ of lifetime income)? A zero balance in our model is represented by total taxes equal to benefits without discounting, to represent all cohorts alive at one time. In contrast, the net tax rate in our model is the discounted present value of one's taxes minus one's own benefits during life. Since taxes come before benefits, discounting means that the present value of taxes outweigh the present value of benefits, for a positive net tax rate. ${ }^{31}$ Aaron and Reischauer (1998) make less-dramatic modifications to social security. As indicated earlier, they would raise some revenue in ways not captured in our model, and they would reduce benefits by raising the number of years of earnings included in the benefit calculation (from 35 to 38 ). This provision is regressive in our model. The A\&R plan would also cut the spousal benefit from one-half to one-third, and it would change the survivor's benefit to three-fourths of the combined benefits of husband and wife. These changes are both somewhat progressive. The fourth column of Table 2 shows that the net effect is slightly progressive. The lowest-income group's net tax rate rises only slightly, from $0.62 \%$ to $0.68 \%$, but the highestincome group's net tax rate rises from $1.01 \%$ to $1.15 \%$. In Figure 1, the A\&R plan starts near the current system and raises net tax rates only slightly with income.

The Moynihan plan has two columns in Table 2 (and two curves in Figure 1). We first calculate the long run effects of the Moynihan plan with a $10.4 \%$ payroll tax (which really only applies to years 2001-2024). Even with this reduced tax, however, net tax rates all rise to at least

${ }^{31}$ However, the net tax rates in this table bear no direct relationship to the annual shortfall shown in the first row. According to the logic in the text, an unfunded "pay as you go" system would have zero annual deficit but positive net tax rates. In contrast, a fully-privatized system would have zero taxes and zero benefits, for a zero annual balance and zero net tax rates. A fully-funded tax-and-benefit scheme could have a zero net tax rate overall but positive annual taxes minus benefits. A related problem not captured in these numbers is that a reform plan may be designed to balance the social security budget in a present value sense, and not necessarily in each year of the long run we calculate. The difference is the transition. A plan may employ higher positive net tax rates in the long run just to help pay for the currently-promised but unfunded benefits to the current generations. 
$2.3 \%$ because this plan incorporates major benefit cuts. It raises the retirement age to 70 , it includes more low-earning years in the benefit calculations, and it reduces indexing by one percentage point. Effectively, each person's real benefits are cut by $1 \%$ per year. Since benefits are progressive, these benefit cuts are regressive. On the other hand, the cut in regressive payroll taxes is progressive. Our table and figure show the net effects, where this version of the Moynihan plan has a very flat net tax rate $(2.38 \%$ on the lowest income group and $2.24 \%$ on the highest income group). ${ }^{32}$ By removing the small amount of progressivity of current law, the change is regressive. Tax rates rise by $1.76 \%$ for the poor group and by $1.23 \%$ for the rich.

The other version of the Moynihan plan employs the eventual 13.4\% tax rate (after 2060), and it is reflected in the sixth column of the table. Net tax rates rise even more, ranging from $4.05 \%$ for the lowest lifetime income group to $3.52 \%$ for the highest lifetime income group. Again the change is regressive, to the point where the entire system is now regressive, As shown in the figure, these net tax rates all lie well above those of any other plan. The reason is related to the switch back to "pay as you go." This plan depletes the current partial funding of social security. Without a trust fund earning a rate of retum, eventual tax rates must be much higher to balance the social security budget year by year.

Current law may not be a relevant comparison, however, if it is not sustainable. Even if policy makers skip these reforms and "do nothing," the budget shortfall may necessitate eventual cuts in benefits or increases in taxes. Therefore, as an alternative basis of comparison, we also show the effects of a proportionate cut in benefits (in the last column of Table 2). Somewhat arbitrarily, we set this benefit cut so that it eliminates half of the current shortfall in our model.

${ }^{32}$ This column is a bit misleading because it uses a short-run tax rate (10.4\% in 2001-24) with a long-run retirement age (which takes effect in 2065). Similarly, the column with the $13.4 \%$ tax rate probably overstates the effects of this plan. The truth may lie in between. 
This amount of benefit cut aids comparability, because it places the net tax rates near the middle of the reform plans (see Figure 1). The result is $18.9 \%$ less benefits for all individuals.

Because the social security benefit formula is progressive, we expect this cut in benefits to be regressive. In fact, the wish to avoid the regressivity of this eventual "forced" cut in benefits would seem to be a reason that policy makers wish to plan ahead by designing their own reforms now. As it turns out, however, this "do nothing" approach is no more regressive than the other planned approaches. In Table 2, the net tax rate rises from $1.56 \%$ on the poor group to $1.89 \%$ on the middle group, and then it falls back to $1.60 \%$ on the rich group. In Figure 1 , the line that represents this proportional benefit cut has the same shape as the lines for the reform plans: mostly flat, with some tendency to rise in the middle of the lifetime income distribution.

\section{Sensitivity Analysis}

We now vary some of the crucial assumptions of the model and see how much these assumptions affect our results. Instead of showing many additional numbers in tables, however, we show only figures. Comparison to Figure 1 then reveals important differences.

First, we consider an increase in the discount rate from $2 \%$ to $4 \%$. As discussed in section 2.6 above, this discount rate is supposed to reflect the alternative rate of retum available to savers. Most studies of social security use a rate like our 2\%, but Caldwell et al (1999) and others argue that the rate should be higher. If so, results might look more like the results with a 4\% discount rate in Figure 2.

As immediately evident from a comparison of Figures 1 and 2, an increase in the discount rate makes all of these social security systems more regressive. Recall that all plans have offsetting effects: payroll taxes in all plans are regressive (because of the wage cap) and benefits 
in all plans are progressive (because of the formula). Yet taxes are paid before retirement, and benefits are received after. Therefore a higher discount rate reduces the weight on these later progressive benefits, and it thereby increases the relative weight on the earlier regressive taxes. Figure 2 shows that net tax rates now slope down for the current system and all reform plans. One plan is not really more regressive than another. The order of the plans is about the same as before, with the lowest net tax rates for current law, followed by A\&R, the benefit cut, and the Moynihan plan. The Moynihan plan with a $13.4 \%$ payroll tax rate still has net tax rates significantly above the other plans. One other noteworthy point is that all systems have higher net tax rates than in Figure 1. The increase in the discount rate reduces the present value of taxes, but it reduces the present value of benefits by more.

Second, we consider a re-definition of lifetime income. Up to this point, we have argued that lifetime potential income should include the value of leisure and time spent at home. We wish to classify individuals from those who are well-off to those who are not, and that time at home provides part of the well-being of those individuals. Consider, for example, one individual who works 40 hours per week at $\$ 10$ per hour and another individual who works 20 hours per week at $\$ 20$ per hour. Previous studies that classify individuals by actual earnings would put both of these individuals into the same income group. Instead, we argue that the second individual is "richer" because he or she has the same take-home pay plus the extra 20 hours per week at home to care for children, cook dinner, clean house, do the gardening, or just relax.

These are the reasons that we assign each individual 4000 hours per year valued at that individual's wage rate. As a consequence, however, this "potential" income may be about twice the value of actual earnings (of a person who works about 2000 hours per year). When we use this larger measure of potential earnings in the denominator of our net social security tax rate calculation, the resulting net tax rates are smaller than in other previous studies. 
To make our results more comparable to previous studies, Figure 3 provides net tax rates based on actual earnings. Specifically, the present value of social security taxes minis benefits is divided by the present value of actual earnings for each group. We do not re-classify individuals into quintiles based on actual earnings. (For comparability with the basic results in Figure 1, we return to the $2 \%$ discount rate of Figure 1.)

When the measure of income in the denominator is cut approximately in half, the net tax as a fraction of income is about twice the size it was before. Otherwise, Figure 3 looks a lot like Figure 1. The current social security system has the lowest overall net tax rates, and is slightly progressive. The A\&R plan has net tax rates that are not much higher and slightly more progressive. The proportional benefit cut has the next higher net tax rates, and it is fairly proportional (rather than progressive). The NCRP plan is then followed by the Moynihan plans, where all are approximately proportional. The high-rate Moynihan plan looks a bit more regressive than the others (just as in Figure 1).

Finally, we consider a different re-definition of lifetime income. Even if all agree that an individual's well-being includes the value of time at home, we still could debate the price at which to value that leisure. Up to this point, leisure has been valued at the individual's wage rate. To the extent that individuals can choose the amount to work, any hour at home must be worth at least that individual's wage rate or else that person would instead have worked that hour.

A problem with this valuation, however, is that a given hour of leisure activity is worth more to a high-wage person than to a low-wage person. Implicitly, the assumption is that the high-wage person gets more well-being or more enjoyment from each hour of leisure. As an alternative, we consider a measurement based on a common set of prices to evaluate all goods that different individuals receive. This alternative takes the view that a person is classified as welloff if he or she gets more goods: more food, more furniture, or more leisure. To see whether one 
person's bundle is worth more than another person's bundle, the researcher would use a given price per unit of each good (such as food, furniture, or leisure). Actual income or actual total expenditures does value purchased goods at the same prices for all individuals, and it can be augmented to value leisure at the same price for all individuals. To value all units of leisure at the same price, we use the average of all individuals' wage rates. The results are shown in Figure 4.

With all individuals' time at home valued at the same wage rate, Figure 4 shows that all social security plans look more progressive. To explain this result, note that the re-valuation of leisure reduces potential income for the high-income group (which raises their net tax rate as a fraction of income), and it raises potential income for anyone with less than the average wage rate (which lower's their net tax rate as a faction of income). The important point is simply that the characterization of any tax system as regressive or progressive depends substantially on the definition of income. Moreover, we have no unambiguous definition of "income,"

Otherwise, again, the differences between the plans are similar to those in other figures above. The current system has the lowest overall net tax rates. The A\&R plan's tax rates are slightly higher and slightly more progressive. The "benefit cut" is next, followed by the NCRP plan and the Moynihan plan. All look progressive in Figure 4, but one is not noticeably more or less progressive than any other.

\section{Conclusion}

This paper uses a lifetime framework to address questions about the progressivity of social security and proposed reforms. We use a large sample of diverse individuals to calculate lifetime income, to classify individuals into income quintiles, and then to calculate the present value net tax in each group. We note, however, that this type of calculation does not answer all questions. In addition to redistributing between income groups, social security also redistributes between 
groups based on age, gender, or family size. Also not addressed here are questions about effects of social security reform on labor supply, savings, and the government budget.

Recent social security reform proposals have many large apparent differences. Some would raise revenue to fund all future promises, and others would deplete the current partial trust fund and return to "pay as you go" financing. Some would remove implicit transfers between groups, and others would enhance them. Some cut the payroll tax, and others increase it. The retirement age may be raised or not, and the benefit formula may be changed or not.

In a lifetime context, we find that these provisions tend to offset each other's effects on progressivity. Each plan has both regressive elements and progressive elements, so the net effect is not necessarily a lot different from the current system. Despite these many differences between the reform plans, we find that they have similar effects on overall progressivity. In our basic calculations, the slightly-progressive current system would be slightly more progressive in the Aaron and Reischauer plan, and it would become slightly regressive in each of the other plans. The pattern of progressivity is affected by alternative assumptions, but it is affected in similar ways for the current system and proposed reforms. None of these reforms greatly alters the current degree of progressivity on a lifetime basis. 


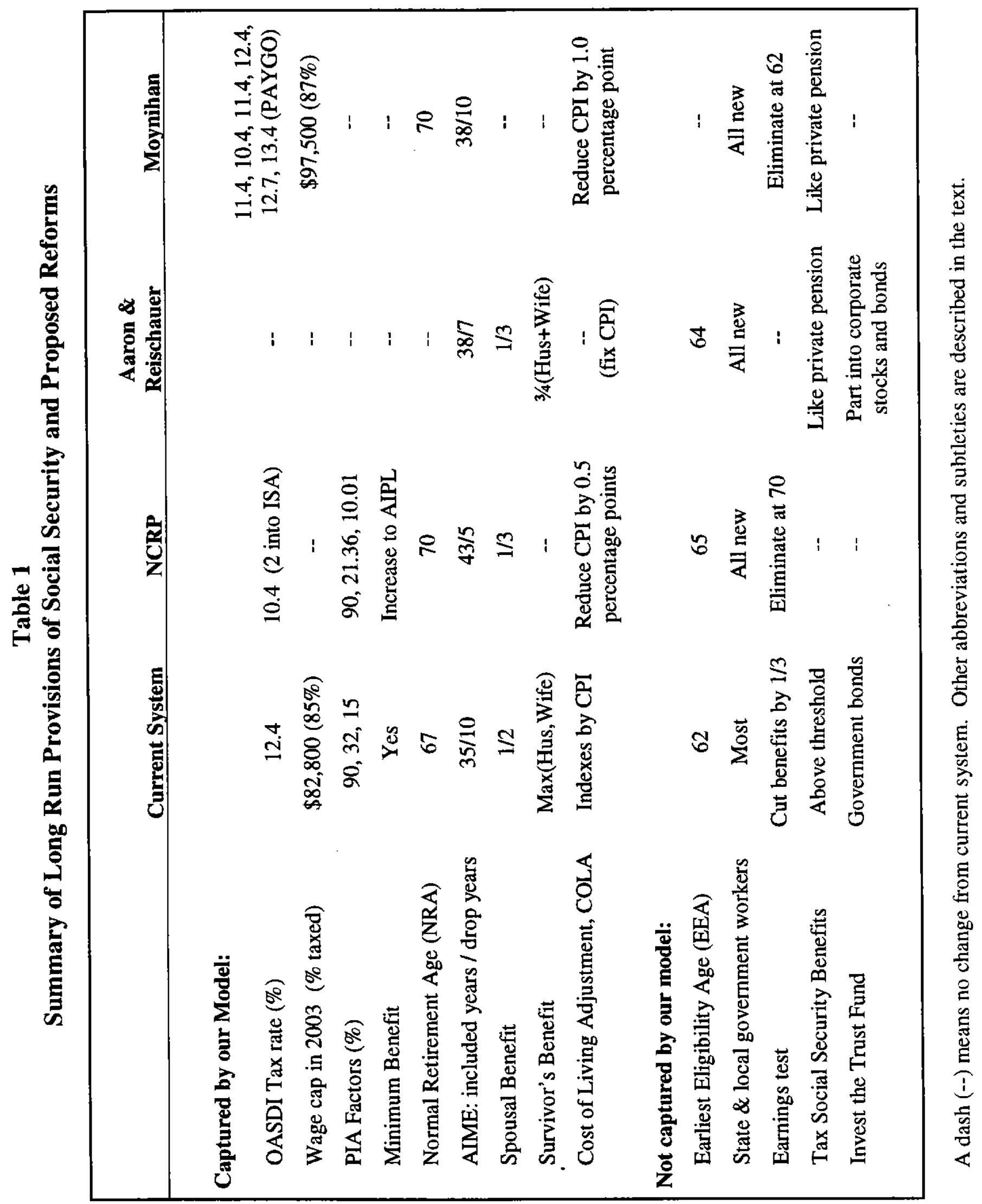




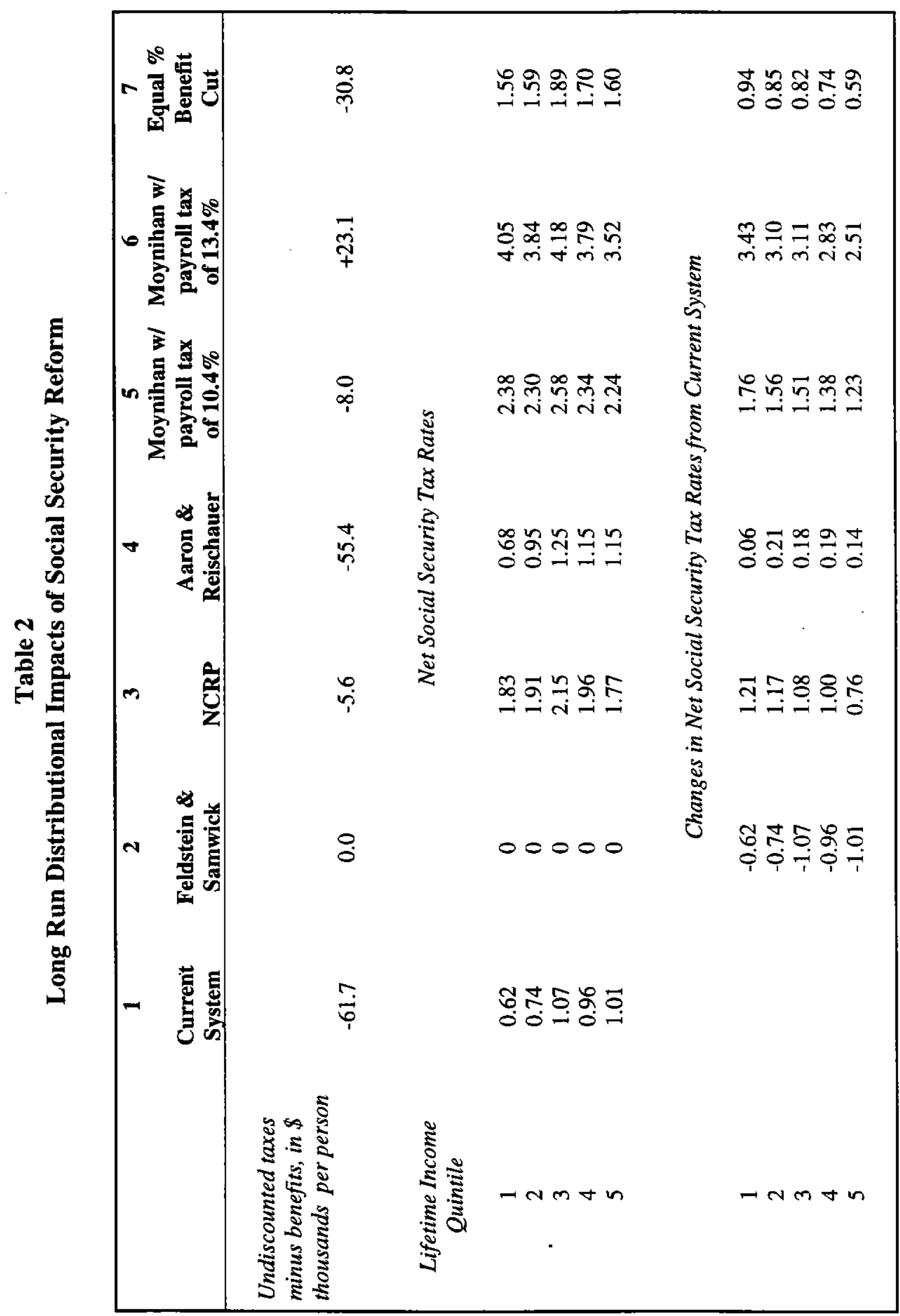




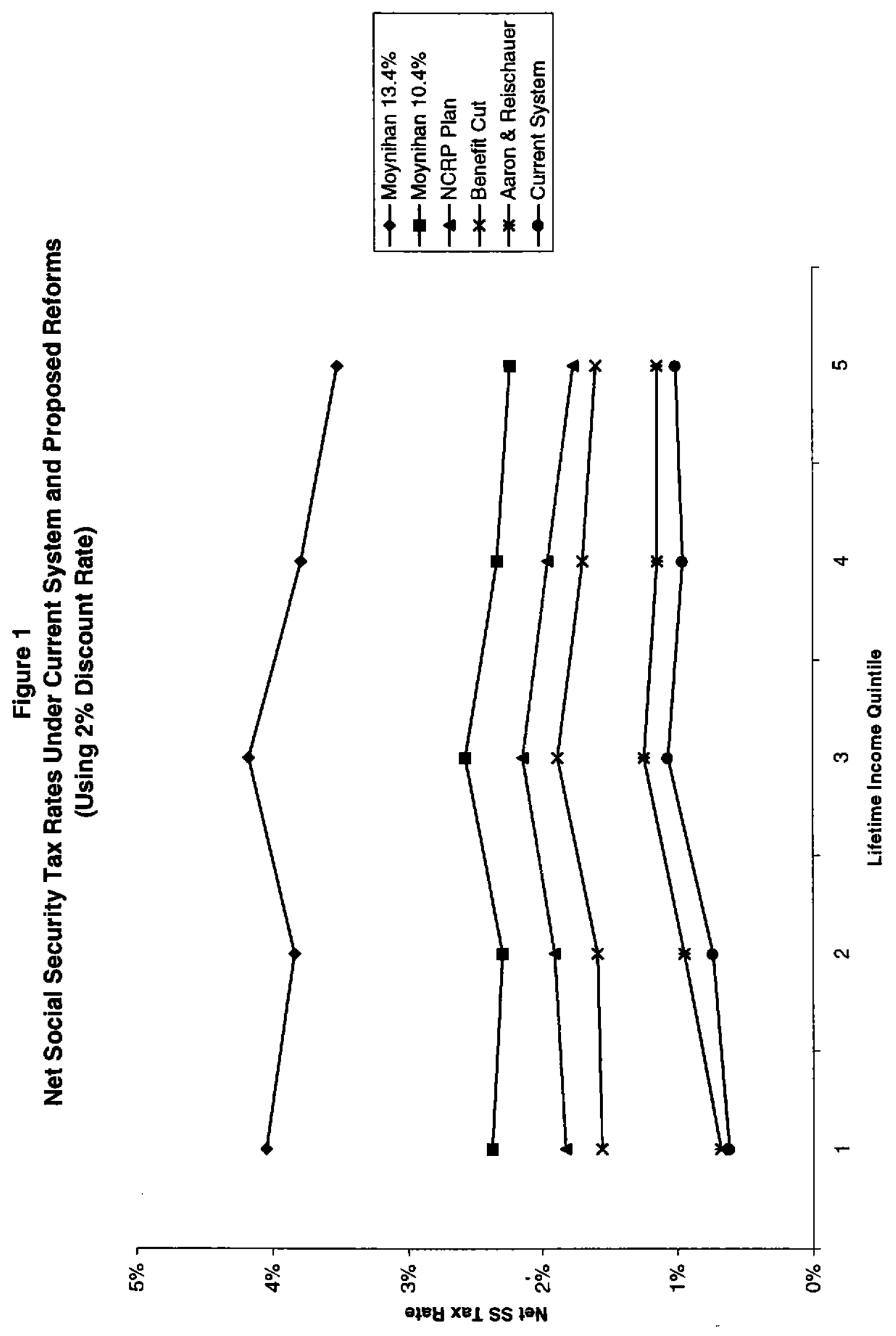




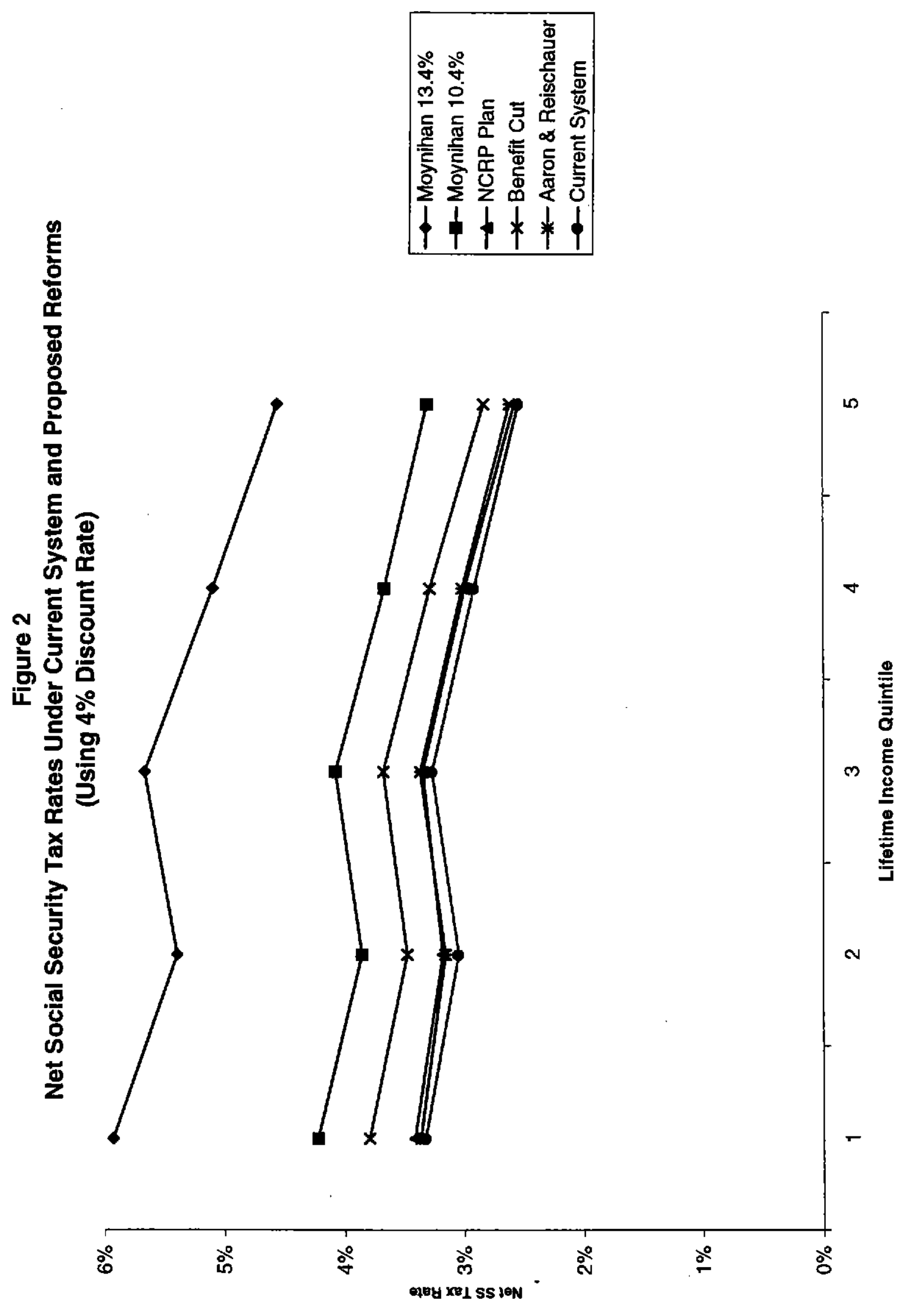



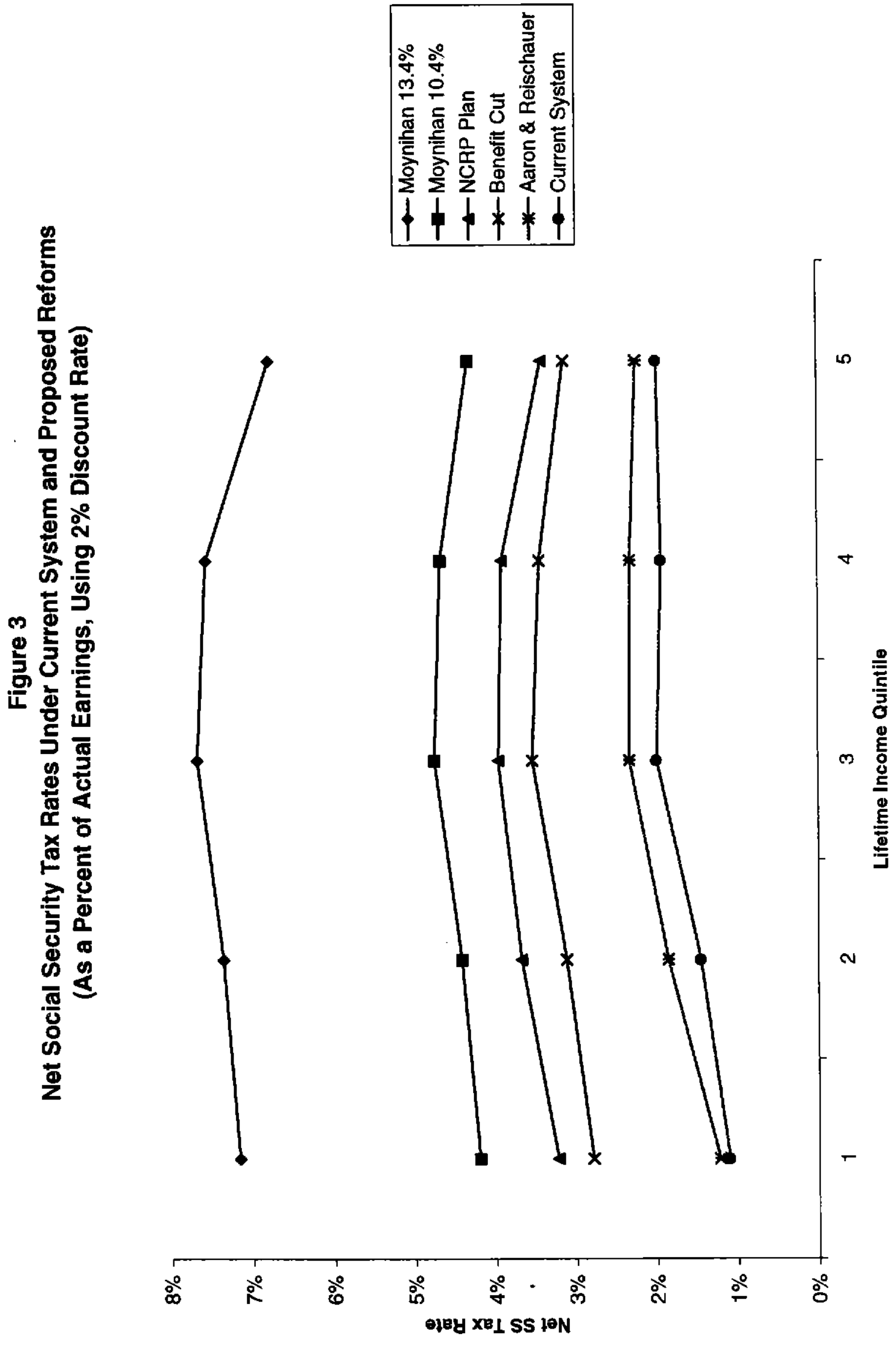


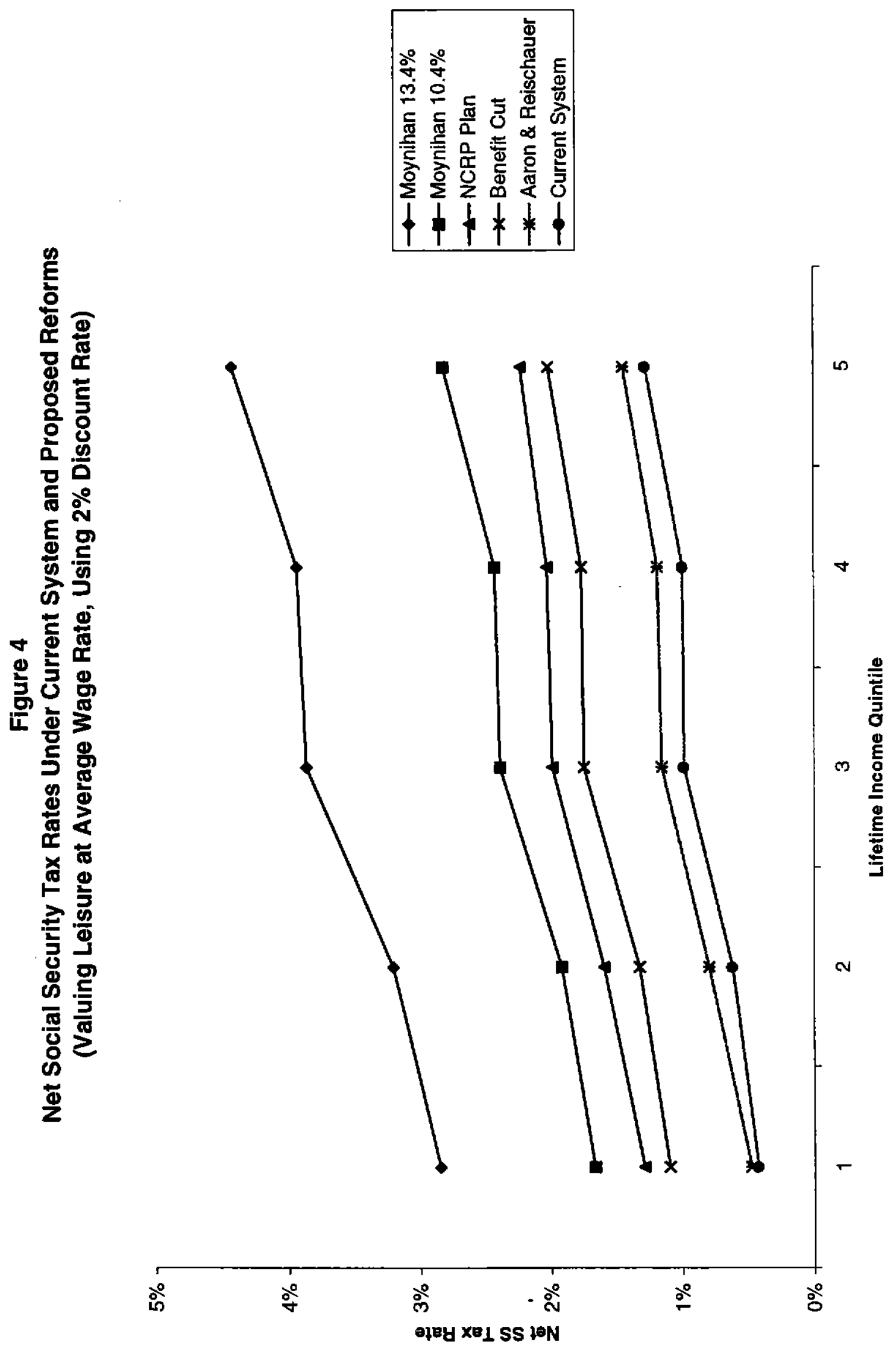




\section{APPENDIX A: DATA AND METHODOLOGY}

This appendix is divided into five parts, describing the selection of the sample from the PSID, the estimation of $\log$ wage regressions and calculation of potential lifetime earnings, the estimation of earnings profiles, the derivation of income-differentiated mortality, and the calculation of social security benefits.

\section{A1. Data and Sample Selection}

We use the PSID for the years 1968 to 1989 , which gives us twenty-two years of data for a sample of the population. We select our sample based on three criteria. First, our sample members are not taken from the low-income subsample of the PSID. While the data contain weights so that the low-income sample can be merged with the representative sample, we felt that the representative sample provided sufficient data for our purposes. Second, we require that sample members remain in the sample for the entire period. Survey respondents may have died, or simply decided that the survey was no longer worth their time. Including those who dropped out of the sample was judged not to be worth the possible distortion in the data and additional computational work required to track these individuals. Third, we only include individuals whose relationship to head status did not change during the sample period.

Because of these criteria, we cut off a group of individuals who were less than 30 in 1968 . We disproportionately eliminate women from the sample, because the PSID always classifies the man of a couple as the head of household. A single man who marries during the period remains head of household and is included in our sample, but a single woman who marries does not maintain the same relationship to head status for the whole period and would be excluded.

Our final sample consists of 1086 heads and 700 wives. It captures 66 percent of the original, non-low-income PSID sample, including 92 percent of heads and 62 percent of wives. Because we did not extract data for those who dropped out of the sample and those who changed their relationship to head status, we cannot formally test whether their exclusion biases the parameters in our wage and earnings regressions. As reflected in Table A1, however, the observable characteristics of our sample are remarkably similar to the original sample. We therefore believe it is unlikely that our econometric estimates are significantly biased, or that our sample selection skews the conclusions we draw about the progressivity of the social security system and various reform proposals.

\section{A2. Log Wage Regressions and the Calculation of Potential Lifetime Income}

As our analysis is intended to reflect a steady state, we abstract from real economic growth that occurred during our sample period. We want to isolate life-cycle movements in wages so that our wage profiles are not specific to one generation during a particular time frame. Adjusting for economic growth and inflation yields lifetime wage profiles that can be used to analyze the distributional impact of social security in a more general, structural sense. We 
therefore adjust the nominal wage rate using the Social Security Administration's Average Wage Index, which reflects growth in average nominal wages over the sample period. Using this index to deflate wages removes the effects of both inflation and real growth in wages.

We want to estimate a separate wage regression for the working wives and the household heads, but we question the idea of pooling the positive observations of the wives who work consistently throughout the sample with those who work only occasionally. We found that a woman would have to work at least 750 hours a year throughout her working life, an amount slightly less than half-time, to have her own social security benefits be greater than the spousal benefits she could receive based on her husband's earnings (assuming she earns the same wage as her husband). Thus, we divide the working wives into two groups based on whether or not they averaged at least 750 hours of work per year throughout the sample. We ran our log wage regressions separately for the two groups, and then ran another one pooling the two groups, in order to perform an F-test. The results suggest that these two groups should indeed be analyzed separately. We therefore estimate three log wage regressions: for household heads, habitual working wives, and occasional working wives.

We regress the log of the wage rate on an individual fixed effect and other variables like age, age-squared, and age-cubed. Because we have a fixed effect for each individual, we cannot use variables that do not vary over time (like race or gender). However, we do include age interacted with education, race, and gender. For the heads of household we use all positive observations of wages, which gives us 19,130 observations on our 1086 heads. The results of this regression are shown in Table A2. Using the resulting fixed effects and coefficients, we then fill in missing observations during the sample period and observations outside the sample period so that each individual has a wage rate for every year of their entire economic life from age 22 to 66 .

For each of the two groups of working women, we take all positive observations and regress the log of the wage rate on an individual fixed effect and variables for age and the interaction between age and education. The PSID does not have a race variable for the wives in the sample. For the wives who averaged more than 750 hours of work annually, we have 5413 observations on 311 women. For those who work occasionally, but less than 750 hours, we have 2292 observations on 296 wives. The results of the log wage regressions for the two groups of working wives can be found in Table A3. For these two groups, we again use the estimated fixed effects and coefficients to fill in missing observations within the sample, and to simulate observations outside the sample, so that each woman has a complete wage profile. For each of the 93 women who did not work at all, we assign them the median fixed effect from the occasional workers and then use the coefficients from this group's regression to fill in an entire profile of potential hourly wages. Using the wage profile for each individual, we calculate the present value of potential lifetime income. We use this income to delineate quintiles.

\section{A3. The Estimation of Earnings Profiles}

For each of our five lifetime income quintiles, we estimate three new regressions for actual earnings of heads, habitual working wives, and part-time working wives. Our dependent variable 
is actual annual earnings. As above, we deflate earnings by the Social Security Administration's Average Wage Index to adjust for both inflation and real economic growth. Since earnings represent a continuous variable truncated at zero, we use a Tobit framework for estimation. Here we assume that earnings is the product of optimal hours of work and a wage rate that is exogenous to the individual. Optimal hours of work can be positive or negative, so optimal earnings can be described as a latent variable, $\mathrm{y}^{*}$ :

$$
y_{i}^{*}=X_{i} \beta+\epsilon_{i}
$$

where $\mathrm{X}$ is a vector of personal characteristics that determine the individual's wage and desired hours of work. We assume that observations of zero hours worked imply that desired hours of work are less than or equal to zero. Actual earnings, $y$, are observed only if $y^{*}$ is greater than zero. If $\mathrm{y}^{*}$ is less than or equal to zero, then actual earnings are zero:

$$
\begin{aligned}
y_{i}=y_{i}{ }^{*} & \text { if } y_{i}{ }^{*}>0 \\
y_{i}=0 & \text { if } y_{i}{ }^{*} \leq 0
\end{aligned}
$$

In the first stage described above, in which we divide people into lifetime income quintiles, our dependent variable was log wages. Thus we use generalized least squares estimation with individual fixed effects. In this second stage, the Tobit model is nonlinear. We judged that the additional programming effort to include fixed effects in our Tobit estimation was not worthwhile, given that such estimation also implies inconsistent parameter estimates (Heckman and MaCurdy 1980). By excluding fixed effects in this stage, we are able to include race, gender, and education variables in the earnings regressions without interacting them with age. For each regression for the heads of household, we begin with independent variables for age, age-squared, age-cubed, education, education-squared, the product of age and education, a dummy variable for whether the head is female, age interacted with the female dummy, and a dummy for whether the head is white. We then eliminate variables that are insignificant. The results of the regressions for heads can be found in Table A4. For wives who averaged more than 750 hours of work a year, we begin with age, age-squared, age-cubed, education, education-squared, the product of age and education. We again eliminate the insignificant regressors. Results for these regressions can be found in Table A5. We follow a similar procedure for wives who average less than 750 hours of work per year, and these results can be found in Table A6.

To simulate out-of-sample observations, we multiply the independent variables of each individual by the appropriate coefficients from their group's earnings regression. In addition, we include a random component, which we obtain by using the estimated standard error of each group's regression (shown in Tables A4-A6) to generate a normally-distributed random variable. This random component is intended to represent unforeseen circumstances that affect earnings. It also means that individuals with the same observed characteristics will not have the exact same earnings profile. Simulated earning observations are thus-calculated as: 


$$
\hat{y}_{i}=X \hat{\beta}+\hat{\epsilon}_{i}
$$

where $\hat{\beta}$ is the vector of estimated coefficients from our earnings regressions, and $\hat{\varepsilon}$ is the random component obtained by using the standard error of the regression to generate a random variable. Using this procedure, both positive and zero observations are generated. We found that the number of zeros generated for each group is consistent with the number of zero observations observed for that group during the sample years.

\section{A4. Derivation of Extended, Income-Differentiated Mortality}

To extend the mortality tables from age 85 through age 99 , we make three assumptions. First, we assume that the probability of remaining alive beyond age 85 decreases annually by a constant amount (Faber and Wade, 1983). Second, we set to zero the probability of remaining alive after age 99 . This age seems a reasonable cut-off point, since less than $0.7 \%$ of all social security beneficiaries are older than 95 (Annual Statistical Supplement, 1995). Third, given these two conditions, we find the constant annual change in the probability each year for each sex-race group is such that the resulting set of probabilities yields the same life expectancy at age 85 as in the Vital Statistics.

Table 7 in Rogot et al (1992) shows information on actual deaths in their sample for each annual income group, within each race-sex-age group. For example, consider white males, ages 25 to 34 . For each range of income (e.g. $\$ 10,000$ to $\$ 14,999$ in 1980 dollars), their table shows the number of individuals in their sample $(\mathrm{N}=14,563)$, the number of observed deaths during the sample period $(\mathrm{O}=115)$, and the number of deaths that would be expected if all income groups had the same mortality rate $(E=92.2)$. They then divide to get the Observed/Expected ratio $(\mathrm{O} / \mathrm{E}=1.25)$. Actual deaths in that low-income group are $25 \%$ higher than what would be expected using tables not differentiated by income.

We know the annual income of every individual in our PSID sample, so we need to exclude the "unknown income" category from the table in Rogot et al (1992). If we simply ignored this category, the overall $\mathrm{O} / \mathrm{E}$ ratio would not be 1.0 for all income groups together. For this reason, we recalculate the expected deaths based on the subset of their individuals for which income is known, and recalculate $\mathrm{O} / \mathrm{E}$ ratios for each group. The average of these new $\mathrm{O} / \mathrm{E}$ ratios is 1.0 , as desired. We then apply the appropriate ratio to each cell. Results for 25-34 year olds are shown in Table A7.

Finally, since annual income is volatile, we do not want to apply these annual-incomedifferentiated $\mathrm{O} / \mathrm{E}$ ratios to the annual income of each person each year. Instead, we base differential mortality on lifetime income, in three steps. First, after we compute the present value of lifetime income for each of the 1,786 in our PSID sample, we assign each individual a ranking compared to all individuals in our sample. For example, an individual whose lifetime income ranks 432 out of the 1,786 individuals is ranked in the $24^{\text {th }}$. percentile. Second, for each of the 
annual income groups in Table A7, we likewise determine percentile rankings based on income (shown in the third column). Third, for each individual in our sample, we match the percentile of their lifetime income to the percentile for the same age-race-sex category in Table A7. For example, a white female aged 27 who has lifetime income at the $24^{\text {th }}$ percentile would be matched to the $\$ 10,000-\$ 14,999$ annual income group (which lies between the $18^{\text {th }}$ percentile and the $36^{\text {th }}$ percentile). That individual would then be assigned that group's $\mathrm{O} / \mathrm{E}$ ratio for white females (1.17). Finally, this ratio is used to scale the probability of death for that individual's age, sex, and race in the Vital Statistics (which are not differentiated by income).

A remaining problem, however, is related to causality: our procedure essentially uses the individual's income as a determinant of death, even though the annual income levels in Table A7 may be determined in part by illness immediately preceding death. This problem is somewhat mitigated by the fact that the CPS data used by Rogot et al (1992) is based on total combined family income, rather than just the decedent's income.

\section{A5. Calculation of Social Security Benefits}

Every variable in this appendix is specific to each individual, but we drop the index $i$ for expositional simplicity. For an unmarried individual, the social security benefit at age $j$ is:

$$
\mathrm{BEN}_{\mathrm{j}}=\mathrm{PIA}_{\mathrm{j}} \times \mathrm{CPI}_{62, \mathrm{j}}
$$

where PIA is the Primary Insurance Amount, $\mathrm{CPI}_{62, \mathrm{j}}$ is the cumulative inflation index from age 62 to the age at which the benefit is computed. Then the mortality-adjusted benefit is:

$$
E_{22}\left(B N_{j}\right)=B E N_{j} \times P_{j}
$$

where $E_{22}\left(B E N_{j}\right)$ is the expected value at age 22 of the benefit to be received at age $\mathrm{j}$, and $P_{j}$ is the conditional probability of survival to age $j$, given survival to age 22 . For married individuals, the basic benefit is computed in the same manner. We compute the spousal benefit for the wife (or analogously, the husband) as:

$$
\mathrm{SpBEN}_{\mathrm{j}}=0.5 \times \operatorname{SBEN}_{\mathrm{js}} \text {, }
$$

where $\operatorname{SpBEN}_{\mathrm{j}}$ is the spousal benefit at wife's age $\mathrm{j}, \mathrm{SBEN}_{\mathrm{js}}$ is the husband's PIA adjusted for inflation to age js, and js is the husband's age when the wife is age $\mathrm{j}$. Similarly, we calculate the survivor benefit:

$$
\operatorname{SurvBEN}_{\mathrm{j}}=\mathrm{SBEN}_{\mathrm{js}}
$$

where SurvBEN $\mathrm{j}_{\mathrm{j}}$ is the wife's survivor benefit after the death of the husband. If the other spouse is alive, we assume that a married individual receives the greater of his or her own benefit (BEN) or the spousal benefit (SpBEN). If the other spouse is deceased, the individual receives the greater of his or her own benefit (BEN) or the survivor benefit (SurvBEN). Using $\mathrm{PH}_{j}$ and $\mathrm{PW}_{\mathrm{j}}$ 
for the husband's and wife's survival probabilities, the husband's mortality-adjusted benefit is:

$$
E_{22}\left(\operatorname{HBEN}_{\mathrm{j}}\right)=\operatorname{PH}_{\mathrm{j}}\left[\mathrm{PW}_{\mathrm{j}} \operatorname{Max}\left(\mathrm{BEN}_{\mathrm{j}}, \operatorname{SpBEN}_{\mathrm{j}}\right)+\left(1-\mathrm{PW}_{\mathrm{j}}\right) \operatorname{Max}\left(\mathrm{BEN}_{\mathrm{j}}, \operatorname{SurvBEN}_{\mathrm{j}}\right)\right]
$$

where $E_{22}\left(\mathrm{HBEN}_{\mathrm{j}}\right)$ is the expected value at age 22 of the husband's benefit. This expected value includes only the dollars going directly to husband. A symmetrical calculation is made to determine the wife's mortality-adjusted benefit:

$$
E_{22}\left(\mathrm{WBEN}_{\mathrm{j}}\right)=\mathrm{PW}_{\mathrm{j}}\left[\mathrm{PH}_{\mathrm{j}} \operatorname{Max}\left(\mathrm{BEN}_{\mathrm{j}}, \mathrm{SpBEN}_{\mathrm{j}}\right)+(1-\mathrm{PH}) \operatorname{Max}\left(\mathrm{BEN}_{\mathrm{j}}, \operatorname{SurvBEN}_{\mathrm{j}}\right)\right]
$$

We then compute the present value of expected taxes and benefits at age 22 for each individual, using alternative values for the constant real discount rate $r$ :

$$
\begin{aligned}
& \operatorname{PVTAX}=\Sigma_{\mathrm{j}}\left[\mathrm{E}_{22}\left(\mathrm{SST}_{\mathrm{j}}\right) /(1+\mathrm{r}) \mathrm{(j-22)}_{(\mathrm{j}-22)}^{(\mathrm{j})},\right. \\
& \operatorname{PVBEN}=\Sigma_{\mathrm{j}}\left[\mathrm { E } _ { 2 2 } \left(\mathrm{BEN}_{\mathrm{j}} /(1+\mathrm{r})^{\mathrm{j}},\right.\right.
\end{aligned}
$$


Table A1

Sample Selection

Original PSID Sample

Sample Used in Analysis

Number of people

Percent under 30

2780

1786

Education of head (percent)

High school diploma

36

25

Cotlege degree

33

12

32

12

Education of wife (percent)

High school diploma

College degree

46

8

50

Race of head (percent)

White

92

7

94

Black

Table A2

Log Wage Regression for Heads of Household

\begin{tabular}{|c|c|c|}
\hline Independent Variable & Coefincient & T-Statistic \\
\hline Age & 0.1343 & 6.26 \\
\hline $\operatorname{age}^{2}$ & $-0,003313$ & -8.53 \\
\hline $\mathrm{age}^{3}$ & 0.000026 & 9.55 \\
\hline age $x$ educ & 0.003669 & 4.87 \\
\hline $\operatorname{age}^{2} x$ educ & -0.0000326 & -4.52 \\
\hline age $x$ fermale & -0.0239 & -1.89 \\
\hline $\operatorname{age}^{2} x$ female & 0.000306 & 2.11 \\
\hline age $x$ white & 0.0167 & 1.32 \\
\hline age $^{2} x$ white & -0.000240 & -1.67 \\
\hline Individuals & & 1,086 \\
\hline Observations & & 19,130 \\
\hline Adjusted R-squared & & 0.57 \\
\hline
\end{tabular}


Table A3

Log Wage Regressions for Wives

\begin{tabular}{|lrrrr|}
\hline Independent Variable & $\begin{array}{l}\text { Habitual } \\
\text { Workers }\end{array}$ & T-Statistic & $\begin{array}{c}\text { Occasional } \\
\text { Workers }\end{array}$ & T-Statistic \\
\hline age & 0.0493 & 1.25 & 0.0104 & 0.102 \\
age $^{2}$ & -0.000647 & -0.949 & 0.000985 & 0.522 \\
age $^{3}$ & 0.0000018 & 0.399 & -0.0000111 & -1.03 \\
age x educ & -0.000252 & -0.106 & -0.00538 & -0.965 \\
age $^{2}$ x educ & 0.0000085 & 0.344 & 0.0000262 & 0.419 \\
\hline & & & & \\
\hline Individuals & & 311 & & 296 \\
Observations & & 5.413 & & 2,292 \\
Adjusted R-squared & & 0.55 & & 0.36 \\
\hline
\end{tabular}

Table A4

Tobit Earnings Regressions for Heads

\begin{tabular}{|c|c|c|c|c|c|}
\hline $\begin{array}{l}\text { Independent } \\
\text { Variable }\end{array}$ & $\begin{array}{c}\text { (Poorest) } \\
\text { First } \\
\text { Quintile } \\
\end{array}$ & $\begin{array}{c}\text { Second } \\
\text { Quintile } \\
\end{array}$ & $\begin{array}{c}\text { Third } \\
\text { Quintile } \\
\end{array}$ & $\begin{array}{l}\text { Fourth } \\
\text { Quintile }\end{array}$ & $\begin{array}{c}\text { (Richest) } \\
\text { Fifth } \\
\text { Quintile }\end{array}$ \\
\hline Constant & $\begin{array}{r}-8132.46 \\
(1.76)\end{array}$ & $\begin{array}{r}-30327 \\
(6.13)\end{array}$ & $\begin{array}{r}-2488.82 \\
(10.20)\end{array}$ & $\begin{array}{r}-85422.4 \\
(12.75)\end{array}$ & $\begin{array}{r}-11116 \\
(5.83)\end{array}$ \\
\hline Age & $\begin{array}{r}1059.26 \\
(5.50)\end{array}$ & $\begin{array}{r}1961.75 \\
(9.92)\end{array}$ & $\begin{array}{r}2389.17 \\
(7.82)\end{array}$ & $\begin{array}{r}4521.45 \\
(22.55)\end{array}$ & $\begin{array}{r}6722.26 \\
(12.54)\end{array}$ \\
\hline $\mathrm{Age}^{2}$ & $\begin{array}{r}-13.64 \\
(6.64)\end{array}$ & $\begin{array}{r}-23.02 \\
(10.61)\end{array}$ & $\begin{array}{r}-35.43 \\
(14.62)\end{array}$ & $\begin{array}{r}-50.39 \\
(22.44)\end{array}$ & $\begin{array}{r}-90.61 \\
(20.95)\end{array}$ \\
\hline Age $x$ educ & & & $\begin{array}{r}54.67 \\
(4.72)\end{array}$ & & $\begin{array}{r}107.59 \\
(4.85)\end{array}$ \\
\hline Educ & $\begin{array}{r}636.43 \\
(6.03)\end{array}$ & $\begin{array}{r}2069.38 \\
(4.93)\end{array}$ & $\begin{array}{r}-3554.69 \\
(2.96)\end{array}$ & $\begin{array}{r}2811.77 \\
(3.77)\end{array}$ & $\begin{array}{r}-1912.73 \\
(1.79)\end{array}$ \\
\hline Educ $^{2}$ & $\begin{array}{r}-5.45 \\
(5.35)\end{array}$ & $\begin{array}{r}-60.97 \\
(3.25)\end{array}$ & $\begin{array}{r}84.76 \\
(2.47)\end{array}$ & $\begin{array}{r}-93.01 \\
(3.18)\end{array}$ & \\
\hline Female & $\begin{array}{r}-15432.5 \\
(5.46)\end{array}$ & $\begin{array}{r}-36378.6 \\
(5.73)\end{array}$ & $\begin{array}{r}-8338.69 \\
(5.80)\end{array}$ & $\begin{array}{r}-7919.65 \\
(5.05)\end{array}$ & $\begin{array}{r}-28415.5 \\
(12.22)\end{array}$ \\
\hline Age $x$ female & $\begin{array}{r}148.24 \\
(2.73)\end{array}$ & $\begin{array}{r}548.23 \\
(4.53)\end{array}$ & & & \\
\hline White & $\begin{array}{r}1785.82 \\
(2.63)\end{array}$ & & $\begin{array}{r}2505.66 \\
(1.91)\end{array}$ & $\begin{array}{r}5242.61 \\
(3.59)\end{array}$ & $\begin{array}{r}13890.8 \\
(5.19)\end{array}$ \\
\hline Sigma* & $\begin{array}{r}15012.6 \\
(81.64)\end{array}$ & $\begin{array}{r}16429.6 \\
(85.09)\end{array}$ & $\begin{array}{r}17149.2 \\
(84.32)\end{array}$ & $\begin{array}{r}18262.5 \\
(89.81)\end{array}$ & $\begin{array}{r}34386.6 \\
(92.16)\end{array}$ \\
\hline $\begin{array}{l}\text { \% positive } \\
\text { observations }\end{array}$ & $90 \%$ & $93 \%$ & $95 \%$ & $96 \%$ & $95 \%$ \\
\hline
\end{tabular}

T-statistics are in parentheses

* sigma is the standard error of the regression 


\section{Table A5}

Tobit Earnings Regressions for Habitually Working Wives

\begin{tabular}{|c|c|c|c|c|c|}
\hline $\begin{array}{c}\text { Independent } \\
\text { Variable }\end{array}$ & $\begin{array}{c}\text { (Poorest) } \\
\text { First } \\
\text { Quintile }\end{array}$ & $\begin{array}{l}\text { Second } \\
\text { Quintile }\end{array}$ & $\begin{array}{c}\text { Third } \\
\text { Quintile }\end{array}$ & $\begin{array}{l}\text { Fourth } \\
\text { Quintile } \\
\end{array}$ & $\begin{array}{c}\text { (Richest) } \\
\text { Fifth } \\
\text { Quintile } \\
\end{array}$ \\
\hline Constant & $\begin{array}{r}-14128.3 \\
(2.53)\end{array}$ & $\begin{array}{r}-4324.5 \\
(0.59)\end{array}$ & $\begin{array}{r}17493.0 \\
(1.18)\end{array}$ & $\begin{array}{r}22901.9 \\
(1.11)\end{array}$ & $\begin{array}{r}29809.2 \\
(0.54)\end{array}$ \\
\hline Age & $\begin{array}{r}1100.17 \\
(7.62)\end{array}$ & $\begin{array}{r}947.28 \\
(4.56)\end{array}$ & $\begin{array}{r}-2154.25 \\
(1.98)\end{array}$ & $\begin{array}{r}-4597.56 \\
(3.09)\end{array}$ & $\begin{array}{r}-11867.6 \\
(5.75)\end{array}$ \\
\hline $\mathrm{Age}^{2}$ & $\begin{array}{r}-12.60 \\
(9.51)\end{array}$ & $\begin{array}{r}-15.03 \\
(7.52)\end{array}$ & $\begin{array}{r}75.45 \\
(2.91)\end{array}$ & $\begin{array}{r}142.90 \\
(3.97)\end{array}$ & $\begin{array}{r}333.48 \\
(6.79)\end{array}$ \\
\hline $\mathrm{Age}^{3}$ & & & $\begin{array}{r}-0.68 \\
(3.44)\end{array}$ & & $\begin{array}{r}-2.85 \\
(7.56)\end{array}$ \\
\hline Age $x$ educ & $\begin{array}{r}10.33 \\
(1.38)\end{array}$ & $\begin{array}{r}46.05 \\
(3.74)\end{array}$ & & $\begin{array}{r}-1.30 \\
(4.64)\end{array}$ & \\
\hline Educ & $\begin{array}{r}-1371.47 \\
(2.27)\end{array}$ & $\begin{array}{r}-1788.95 \\
(3.06)\end{array}$ & $\begin{array}{r}190.0 \\
(1.52)\end{array}$ & $\begin{array}{r}3522.4 \\
(3.39)\end{array}$ & $\begin{array}{r}15155.1 \\
(2.14)\end{array}$ \\
\hline Educ $^{2}$ & $\begin{array}{r}64.97 \\
(3.18)\end{array}$ & & & $\begin{array}{r}-88.25 \\
(2.13)\end{array}$ & $\begin{array}{r}-510.36 \\
(2.10)\end{array}$ \\
\hline Sigma * & $\begin{array}{r}6392.47 \\
(52.55)\end{array}$ & $\begin{array}{r}8777.5 \\
(46.22)\end{array}$ & $\begin{array}{r}10216.4 \\
(48.26)\end{array}$ & $\begin{array}{r}11548.4 \\
(39.36)\end{array}$ & $\begin{array}{r}15471.3 \\
(37.76)\end{array}$ \\
\hline $\begin{array}{l}\text { \% positive } \\
\text { observations }\end{array}$ & $84 \%$ & $83 \%$ & $84 \%$ & $85 \%$ & $84 \%$ \\
\hline
\end{tabular}

T-statistics are in parentheses

* sigma is the standard error of the regression

\section{Table A6}

Tobit Earnings Regressions for Part-time Working Wives

\begin{tabular}{|c|c|c|c|c|c|}
\hline $\begin{array}{c}\text { Independent } \\
\text { Variable }\end{array}$ & $\begin{array}{c}\text { (Poorest) } \\
\text { First } \\
\text { Quintile } \\
\end{array}$ & $\begin{array}{l}\text { Second } \\
\text { Quintile } \\
\end{array}$ & $\begin{array}{c}\text { Third } \\
\text { Quintile } \\
\end{array}$ & $\begin{array}{l}\text { Fourth } \\
\text { Quintile } \\
\end{array}$ & $\begin{array}{c}\text { (Richest) } \\
\text { Fifth } \\
\text { Quintile } \\
\end{array}$ \\
\hline Constant & $\begin{array}{r}2738.87 \\
(1.06)\end{array}$ & $\begin{array}{r}2049.33 \\
(0.13)\end{array}$ & $\begin{array}{r}-27560.4 \\
(2.83)\end{array}$ & $\begin{array}{r}-29957 \\
(5.88)\end{array}$ & $\begin{array}{r}108105 \\
(4.26)\end{array}$ \\
\hline Age & $\begin{array}{r}-68.30 \\
(1.58)\end{array}$ & $\begin{array}{r}-2970.23 \\
(3.14)\end{array}$ & $\begin{array}{r}1505.06 \\
(5.60)\end{array}$ & $\begin{array}{r}739.21 \\
(5.03)\end{array}$ & $\begin{array}{r}-10479.2 \\
(5.72)\end{array}$ \\
\hline $\mathrm{Age}^{2}$ & & $\begin{array}{c}86.98 \\
(4.06)\end{array}$ & $\begin{array}{r}-16.69 \\
(5.73)\end{array}$ & $\begin{array}{r}-9.12 \\
(5.49)\end{array}$ & $\begin{array}{r}267.93 \\
(6.28)\end{array}$ \\
\hline $\mathrm{Age}^{3}$ & & $\begin{array}{r}-0.69 \\
(4.30)\end{array}$ & & & $\begin{array}{l}-2.156 \\
(6.69)\end{array}$ \\
\hline Age $x$ educ & & $\begin{array}{r}-50.12 \\
(3.59)\end{array}$ & & & \\
\hline Educ & $\begin{array}{r}-409.04 \\
(2.96)\end{array}$ & $\begin{array}{r}4947.28 \\
(4.24)\end{array}$ & $\begin{array}{r}-2579.5 \\
(1.78)\end{array}$ & $\begin{array}{r}1870.71 \\
(2.59)\end{array}$ & $\begin{array}{r}1219.79 \\
(7.05)\end{array}$ \\
\hline Educ $^{2}$ & & $\begin{array}{r}-119.18 \\
(2.86)\end{array}$ & $\begin{array}{r}138.56 \\
(2.25)\end{array}$ & $\begin{array}{r}-58.73 \\
(2.01)\end{array}$ & $\begin{array}{r}-12.19 \\
(7.53)\end{array}$ \\
\hline Sigma * & $\begin{array}{r}9067.14 \\
(17.96)\end{array}$ & $\begin{array}{r}6708.64 \\
(25.78)\end{array}$ & $\begin{array}{r}9759.96 \\
(24.70)\end{array}$ & $\begin{array}{r}7926.30 \\
(35.60)\end{array}$ & $\begin{array}{r}12086 \\
(30.62)\end{array}$ \\
\hline $\begin{array}{l}\% \text { positive } \\
\text { observations }\end{array}$ & $31 \%$ & $28 \%$ & $26 \%$ & $39 \%$ & $34 \%$ \\
\hline
\end{tabular}

T-statistics are in parentheses

* sigma is the standard error of the regression 
Table A7

Ratio of Observed Deaths to Expected Deaths (O/E)

for Each Race-Sex Group

Ages 25-34

\begin{tabular}{|cccccccc|}
\hline $\begin{array}{l}\text { Annual } \\
\text { Family } \\
\text { Income }\end{array}$ & $\begin{array}{c}\text { Number } \\
(\mathbf{n})\end{array}$ & Percentile & $\begin{array}{c}\mathbf{O} / \mathbf{E} \\
\text { White Male }\end{array}$ & $\begin{array}{c}\text { O/E } \\
\text { White } \\
\text { Fem. }\end{array}$ & $\begin{array}{c}\text { O/E } \\
\text { Other } \\
\text { Male }\end{array}$ & $\begin{array}{c}\text { O/E } \\
\text { Other } \\
\text { Fem. }\end{array}$ \\
\hline$<\$ 5,000$ & 11,670 & $6.31 \%$ & 1.68 & 1.51 & 1.54 & 1.86 \\
$\$ 5,000-\$ 9,999$ & 22,085 & $18.25 \%$ & 1.20 & .97 & .81 & 1.01 \\
$\$ 10,000-\$ 14,999$ & 33,331 & $36.27 \%$ & 1.28 & 1.17 & 1.36 & 1.01 \\
$\$ 15,000-\$ 19,999$ & 32,231 & $53.70 \%$ & 1.12 & .76 & .71 & .84 \\
$\$ 20,000-\$ 24,999$ & 30,729 & $70.31 \%$ & .80 & .97 & .92 & .36 \\
$\$ 25,000-\$ 49,999$ & 48,375 & $96.47 \%$ & .73 & .94 & .72 & .44 \\
$>\$ 49,999$ & 6,529 & $00,00 \%$ & .61 & 1.15 & .72 & .44 \\
\hline Totals & 184,950 & & $\mathrm{n}=81,461$ & $\mathbf{n}=85,047$ & $\mathrm{n}=7,752$ & $\mathrm{n}=10,690$ \\
\hline
\end{tabular}

Ages 65-74

\begin{tabular}{|rrrlllll|}
\hline $\begin{array}{l}\text { Annual } \\
\text { Family } \\
\text { Income }\end{array}$ & $\begin{array}{c}\text { Number } \\
(\mathbf{n})\end{array}$ & Percentile & $\begin{array}{c}\text { O/E } \\
\text { White Male }\end{array}$ & $\begin{array}{c}\text { O/E } \\
\text { White } \\
\text { Fem. }\end{array}$ & $\begin{array}{c}\text { O/E } \\
\text { Other } \\
\text { Male }\end{array}$ & $\begin{array}{c}\text { O/E } \\
\text { Other } \\
\text { Fem. }\end{array}$ \\
\hline$<\$ 5,000$ & 13,386 & $6.65 \%$ & 1.39 & 1.23 & 1.15 & 1.06 \\
$\$ 5,000-\$ 9,999$ & 20,418 & $49.83 \%$ & 1.19 & 1.06 & .99 & 1.00 \\
$\$ 10,000-\$ 14,999$ & 13,774 & $70.13 \%$ & .98 & .88 & .95 & .85 \\
$\$ 15,000-\$ 19,999$ & 7,082 & $80.57 \%$ & .75 & .93 & .79 & .91 \\
$\$ 20,000-\$ 24,999$ & 4,868 & $87.75 \%$ & .79 & .74 & .92 & .85 \\
$\$ 25,000-\$ 49,999$ & 6,669 & $97.62 \%$ & .73 & .80 & .79 & .87 \\
$>\$ 49,999$ & 1,614 & $00.00 \%$ & .59 & .79 & .79 & .87 \\
\hline Totals & 67,841 & & $\mathbf{n = 2 7 , 2 4 5}$ & $\mathbf{n = 3 4 , 7 2 7}$ & $\mathrm{n=2,452}$ & $\mathrm{n}=3,417$ \\
\hline
\end{tabular}

Source: Rogot, et al (1992), Table 7. The "expected" number of deaths is based on the overall death rate within the age-sex-race category, not differentiated by income, while "observed" deaths are the actual number of deaths in each income group. 


\section{References}

Aaron, Henry J. 1977. "Demographic Effects on the Equity of Social Security Benefits." in M. Feldstein and R. P. Inman, eds., The Economics of Public Services. London: Macmillan.

Aaron, Henry J. and Robert D. Reischauer. 1998. Countdown to Reform. New York: The Century Foundation Press.

Altig, David, Alan J. Auerbach, Laurence J. Kotlikoff, Kent A. Smetters, and Jan Walliser. 1997. "Simulating U.S. Tax Reform." Washington, DC: Congressional Budget Office.

Auerbach, Alan J. and Laurence J. Kotlikoff. 1987. Dynamic Fiscal Policy. New York: Cambridge University Press.

Boskin, Michael J., Laurence J. Kotlikoff, Douglas J. Puffert, and John B. Shoven. 1987. "Social Security: A Financial Appraisal Across and Within Generations". National Tax Journal 40 (March): 19-34.

Brown, Jeffrey. 2000. "Differential Mortality and the Value of Individual Account Retirement Annuities," in Martin Feldstein and Jeff Liebman, eds., The Distributional Effects of Social Security Reform, Chicago: University of Chicago Press.

Burkhauser, Richard V. and Jennifer Warlick. 1981. "Disentangling the Annuity from the Redistributive Aspects of Social Security". The Review of Income and Wealth 27 (December): 401-421.

Caldwell, Steven, Melissa Favreault, Alla Gantman, Jagdeesh Gokhale, Thomas Johnson, and Laurence J. Kotlikoff. 1999. "Social Security's Treatment of Postwar Americans." Tax Policy and the Economy 13, Cambridge, MA: MIT Press.

Coronado, Julia Lynn, Don Fullerton, and Thomas Glass. 2000. "The Progressivity of Social Security," Cambridge, MA: NBER Working Paper \#7520.

Coronado, Julia Lynn, Don Fullerton, and Thomas Glass. 1999. "Distributional Impacts of Proposed Changes to the Social Security System," Tax Policy and the Economy 13, Cambridge, MA: MIT Press.

Duggan, James E., Robert Gillingham and John S. Greenlees. 1993. "Returns Paid to Early Social Security Cohorts”. Contemporary Policy Issues 11 (October): 1-13.

Duggan, James E., Robert Gillingham and John S. Greenlees. 1995. "Progressive Returns to Social Security? An Answer from Social Security Records." Research Paper No. 9501, Washington, DC: U.S. Treasury Department, Office of Economic Policy.

Duleep, Harriett Orcutt. 1986. "Measuring the Effect of Income on Adult Mortality Using the Longitudinal Administrative Record Data". Journal of Human Resources 21 (Spring): 238-251. 
Faber, Joseph F., and Alice H. Wade. 1983. Life Tables for the United States: 1900-2050. Actuarial Study No. 89, Office of the Actuary. Washington, DC: Social Security Administration.

Feldstein, Martin and Andrew Samwick. 1998. "The Transition Path in Privatizing Social Security," in Martin Feldstein, ed., Privatizing Social Security, Chicago: University of Chicago Press.

Flowers, Marilyn and John B. Horowitz. 1993. "Distributional Implications of the Social Security Spouse Benefit". Southern Economic Journal 60 (October): 490-494.

Fox, Alan. 1982. "Earnings Replacement Rates and Total Income: Findings from the Retirement History Study". Social-Security-Bulletin 45 (October): 3-23.

Fullerton, Don and Diane Lim Rogers. 1993. Who Bears the Lifetime Tax Burden? Washington, DC: The Brookings Institution.

Garrett, Daniel M. 1995. "The Effects of Differential Mortality Rates on the Progressivity of Social Security". Economic Inquiry 7 (July): 457-475.

Geanokopolos, John, Olivia S. Mitchell, and Stephen P. Zeldes. 1998. 'Social Security Money's Worth." Cambridge, MA: NBER Working Paper \#6722.

Gramlich, Edward M. 1996. "Different Approaches for Dealing with Social Security". Joumal of Economic Perspectives 10 (Summer): 55-66.

Hamermesh, Daniel S. and Albert Rees. 1993. The Economics of Work and Pay. New York: Harper Collins College Publishers.

Heckman, James J. and Thomas E. MaCurdy. 1980. "A Life Cycle Model of Female Labor Supply." Review of Economic Studies 47 (January): 47-74.

Hurd, Michael D. and John B. Shoven. 1985. "The Distributional Impact of Social Security" in David A. Wise, ed., Pensions, Labor, and Individual Choice, Chicago: University of Chicago Press for NBER.

Ibbotson Associates. 1998. Stocks, Bonds, Bells, and Inflation 1998 Yearbook. Chicago: Ibbotson Associates.

Kotlikoff, Laurence J., Kent A. Smetters, and Jan Walliser. 1998. "Social Security: Privatization and Progressivity." American Economic Review 88 (May): 137-141.

Lee, Julie, Mark McClellan, and Jonathan Skinner. 1999. "Who Benefits from Medicare?" Tax Policy and the Economy 13, Cambridge, MA: MIT Press.

Liebman, Jeffrey B. 2000. "Redistribution in the Current U.S. Social Security System," in Martin Feldstein and Jeff Liebman, eds., The Distributional Effects of Social Security Reform, Chicago: University of Chicago Press. 
Moynihan, Daniel Patrick. 1999. "Social Security Solvency Act of 1998: Brief Description of Provisions". Washington, DC: U.S. Senate.

Myers, Robert J. and Bruce D. Schobel. 1983. "A Money's-Worth Analysis of Social Security Retirement Benefits". Society of Actuaries Transactions 35 (October): 533-561.

National Commission on Retirement Policy (NCRP). 1999. "The 21 st Century Retirement Security Plan". Washington, DC: Center for Strategic and International Studies.

Nelissen, Jan H. M. 1998. "Annual versus Lifetime Income Redistribution by Social Security". Journal of Public Economics 68 (May): 223-249.

Panis, Constantijn W. A. and Lee A. Lillard. 1996. "Socioeconomic Differentials in the Returns to Social Security." RAND Labor and Population Program Working Paper Series 96-05. Santa Monica, CA: RAND Distribution Services.

Pechman, Joseph A. and Benjamin A. Okner. 1974. Who Bears the Tax Burden? Washington, DC: The Brookings Institution.

Rofman, Rafel Paulino. 1993. Social Security and Income Distribution: Mortality and Equity in Pension Plans. Ph.D. Dissertation (Demography). Berkeley, CA: University of Califomia.

Rogot, Eugene, Paul D. Sorlie, Norman J. Johnson, and Catherine Schmitt. 1992. A Mortality Study of 1.3 Million Persons by Demographic, Social, and Economic Factors: 19791985 Follow-Up. National Institutes of Health: NIH Publication 92-3297.

Steuerle, C. Eugene and Jon M. Bakija. 1994. Retooling Social Security for the $21^{\text {st }}$ Century: Right and Wrong Approaches to Reform. Washington, DC: Urban Institute Press.

U.S. Congressional Budget Office. 1999. Raising the Earliest Age for Social Security Benefits. Washington, DC.

U.S. Department of Health and Human Services. 1993. Vital Statistics of the United States 1989. Hyattsville, MD: Public Health Service, Centers for Disease Control and Prevention, National Center for Health Statistics.

U.S. Social Security Administration. 1997. Annual Statistical Supplement, 1997. Social Security Bulletin. Washington DC: U.S. Government Printing Office.

U.S. Social Security Administration. 1998. The 1998 Annual Report of the Board of Trustees of the Federal Old-Age and Survivors Insurance and Disability Insurance Trust Funds.

Washington, DC: U.S. Government Printing Office.

Williams, Roberton C. III. 1998. "Equity in Social Security Benefit Determination: The Effect of Ignoring Some Working Years." Department of Economics, Stanford University. 